\title{
The Case for Market Damages: Revisiting the Lost Profits Puzzle
}

\author{
Robert E. Scott $\dagger$
}

An old and cardinal rule of contract law requires that expectancy damages for breach of contract put the injured party in the position she would have occupied had the contract been performed. ${ }^{1}$ Courts and commentators have accepted this full performance compensation principle as the central objective of the expectancy remedy, pursuant to which they have developed many more precise formulas for various types of cases. ${ }^{2}$ But the simplicity of the full performance principle disguises substantial problems in its application. One of the least recognized of these problems is the tendency of courts and commentators to determine the contractual expectancy ex post (from circumstances that exist at the time for performance) rather than ex ante (from economic opportunities fixed at the moment of contract).

Consider the choice between market damages and lost profits in breached contracts for the sale of goods traded in well-developed markets. ${ }^{3}$ Where a contract calls for delivery of goods traded

$\dagger$ Lewis F. Powell, Jr., Professor of Law and Member, Center for Advanced Studies, University of Virginia.

This article has benefited from numerous discussions with Charles Goetz, who deserves equal credit for any insights it contributes. I would also like to thank Bob Cooter, John Donohue, Daniel Friedmann, Tom Jackson, Saul Levmore, Paul Mahoney, Menachem Mautner, Alan Schwartz, Paul Stephan, Bill Stuntz, and the participants at the Symposium on Modern Contract Law, Tel-Aviv University, March 25-27, 1990, for their helpful comments on earlier versions of this article.

${ }^{1}$ See, for example, Robinson v Harman, 154 Eng Rep 363 (Exch 1848).

${ }^{2}$ See E. Allan Farnsworth, Contracts $\S 12.1$ at $146-49$; $\$ 12.8$ at $185-86$; $\S 12.9$ at $196-98$ (Little, Brown, 2d ed 1990). The Uniform Commercial Code provides one of numerous examples of the salience of full performance compensation: "The remedies provided by this Act shall be liberally administered to the end that the aggrieved party may be put in as good a position as if the other party had fully performed. . . " American Law Institute, Uniform Commercial Code §1-106(1) (West, 2d ed 1987) ("UCC"). Courts echo this theme. See, for example, Western Geophysical Co. of America, Inc. $v$ Bolt Associates, Inc., 584 F2d 1164,1172 (2d Cir 1978) (proper measure of contract damages is the "amount necessary to put [plaintiff] in as good a position as [it] would have been if the defendant had abided by the contract" (quoting Perma Research \& Development Co. $v$ The Singer Co., 402 F Supp 881, 898 (S D NY 1975))).

${ }_{3}$ Market damages and lost profits represent different conceptions of contractual expectancy. The choice between them does not implicate the fundamental choice between expec- 
in a fluctuating market, the market itself fixes the value of the supplier's performance. Thus, common law courts and subsequent statutory codifications typically have regarded the difference between the contract price and the market price at the time of delivery as the proper measure of recovery. This sum, combined with the proceeds of any market purchase or resale, will ordinarily equal full performance compensation.

In some situations, however, had the seller delivered the goods and the buyer accepted them, the injured party would not have derived its economic gain from the fluctuation in market value. Such was the case in Nobs Chemical, U.S.A., Inc. v Koppers Co., Inc., ${ }^{4}$ where the seller entered into a fixed-price supply contract with a Brazilian firm to acquire the contract goods for the buyer. The contract guaranteed the seller a $\$ 95,000$ profit on the deal. Thereafter, the market price for the contract goods fell dramatically. Before the seller acquired the goods from the supplier, the buyer breached. After the seller secured a release from the supplier, it sued for damages of $\$ 300,000$ measured by the difference between the contract price and the market price at the time for performance. ${ }^{5}$ Finding the claim for market damages excessive, the court limited the seller to the $\$ 95,000$ profit it would have earned had the contract been performed. ${ }^{8}$

The concern that market damages may overcompensate is mirrored by the concern that they may undercompensate. For example, market damages are often thought to deny a "volume" seller full recovery for the loss of a sale that cannot be replaced by reselling the goods to another buyer on the market. Most courts at common law and under the various sales acts limited the volume

tation and reliance damages, discussed in Charles Goetz and Robert E. Scott, Enforcing Promises: An Examination of the Basis of Contract, 89 Yale L J 1261 (1980).

4616 F2d 212 (5th Cir 1980).

- Market damages will exceed the post-breach economic loss of the injured party only in cases such as Nobs Chemical where the contract between the aggrieved party and the third party is contingent or the aggrieved party negotiates a release from liability. Otherwise, market damages will equal ex post economic loss, because the aggrieved party must pay compensatory damages to the third party.

${ }^{6} 616$ F2d at 216-17. For a more complete discussion of Nobs Chemical and related cases, see text accompanying notes 66-74. An analogous problem occurs when the seller breaches a fixed price contract (after the market rises) and the buyer has, before breach, contracted to resell the goods at a fixed price to a remote purchaser. In this case, modern courts have been similarly inclined to limit the buyer to its lost profit measured by the difference between the contract price and the resale price, rather than awarding full market damages based on the market price at the time for performance. See, for example, Allied Canners \& Packers, Inc. v Victor Packing Co., 162 Cal App 3d 905, 209 Cal Rptr 60 (1984) and text accompanying notes $76-78$. 
seller to market damages whenever there was an available market for the goods. ${ }^{7}$ But the adoption of the Uniform Commercial Code ${ }^{8}$ stimulated a reconsideration of the common law rule and led to new challenges to the use of market damages for breach of contracts with retailers, jobbers, and other volume sellers. ${ }^{\circ}$

The perceived inadequacies of market damages have sparked vigorous academic debate. Some commentators have suggested that market damages invariably fail to mirror full performance compensation and should be replaced in all cases by direct proof of the profits the injured party anticipated from the breached contract. ${ }^{10}$ Others have argued for selective expansion in the use of lost profits measures. ${ }^{11}$ In each case, the arguments proceed from the common assumption that market damages provide an inaccurate measure of the injured party's loss. This sustained criticism has driven many courts to retreat to the simple commands of the full performance principle. ${ }^{12}$ The resulting trend toward lost prof-

${ }^{7}$ See, for example, Rodocanachi, Sons \& Co. v Milburn Bros., 18 QBD 67 (1886); United States v Burton Coal Co., 273 US 337 (1927); Uniform Sales Act §64(3); Arthur Corbin, 5 Contracts $\S 1100$ (West, 1951). See also Masterton \& Smith v Mayor of Brooklyn, 7 Hill 61, 72 (NY 1845); Charles McCormick, Handbook on the Law of Damages $\S 173$ at 658-60 (West, 1935); Samuel Williston, 2 The Law Governing Sales of Goods at Common Law and Under the Uniform Sales Act $\S 582$ at 1434 (Baker, Voorhis, 2d ed 1924).

${ }^{8}$ The UCC incorporates the traditional market damages measures in $\S$ 2-706 and 2708(1) (sellers' damages) and §§ 2-712 and 2-713 (buyers' damages). The aggrieved party may promptly cover on the market using the contract price-resale (cover) price differential, or rely on hypothetical market opportunities by proving the contract price-market price differential. The UCC authorizes the direct recovery of lost profits only when neither market alternative approximates the full performance position (§ 2-708(2)). For a discussion of the UCC damages scheme from the perspective advanced in this paper, see Part III.B.

${ }^{\circ}$ See generally James J. White and Robert S. Summers, 1 Uniform Commercial Code $\S \S 7-8$ to 7-14 (West, 3d ed 1988); Robert Childres, Buyer's Remedies: The Danger of Section 2-713, $72 \mathrm{Nw}$ U L Rev 837 (1978); Robert Childres and Robert Burgess, Seller's Remedies: The Primacy of UCC 2-708(2), 48 NYU L Rev 833 (1973); Robert J. Harris, A Radical Restatement of the Law of Seller's Damages: Sales Act and Commercial Code Results Compared, 18 Stan L Rev 66 (1965); Robert J. Harris, A General Theory for Measuring Seller's Damages for Total Breach of Contract, 60 Mich L Rev 577 (1962); Ellen A. Peters, Remedies for Breach of Contracts Relating to the Sale of Goods Under the Uniform Commercial Code: A Roadmap for Article Two, 73 Yale L J 199, 273-75 (1963).

${ }_{10}$ See, for example, Childres and Burgess, 48 NYU L Rev at 833 (cited in note 9) and Childres, $72 \mathrm{Nw}$ U L Rev at 837 (cited in note 9).

${ }^{11}$ See Robert Cooter and Melvin Aron Eisenberg, Damages for Breach of Contract, 73 Cal L Rev 1434 (1985); Victor P. Goldberg, An Economic Analysis of the Lost-Volume Retail Seller, 57 S Cal L Rev 283 (1984); John A. Sebert, Remedies Under Article Two of the Uniform Commercial Code: An Agenda for Review, $130 \mathrm{U}$ Pa L Rev 360 (1981); and William L. Schlosser, Construing UCC Section 2-708(2) to Apply to the Lost-Volume Seller, 24 Case W Res L Rev 686 (1973).

${ }^{12}$ Cases awarding lost profits because market damages were seen as exceeding full performance compensation are collected in note 60 . Cases holding market damages inadequate to achieve full performance compensation are collected in note 38 . 
its awards seems to have completely reversed the longstanding common law preference for market damages. ${ }^{13}$

This article argues that the modern development is unfortunate and results from an incomplete understanding of the function of damage rules and the meaning of full performance compensation. Damage rules are contract terms. They do not merely measure losses differently; they allocate risks between the parties differently. Lost profits damages reflect an ex post perspective. They measure the value of the completed contract based on what the parties actually did. Market damages, on the other hand, apply a measure of events extrinsic to the parties' behavior. Before one measures damages, therefore, one must first decide how the parties expressly or impliedly allocated the relevant market risks. ${ }^{14}$ The question is not which damage rule better protects a given economic advantage. Rather, the question is what economic advantage the contract protects. In short, before one can place the injured party in the same position as if the parties had performed the contract, one must know which perspective on risk allocation the contract adopts.

In Part I, I review the current debate over alternative damage rules. The confusion in the literature stems from two related problems: the failure of legal analysts to distinguish between ex ante and ex post perspectives, and the failure of economic analysts to distinguish between ideal damages and more pragmatic default rules suitable for the broadest number of bargainers. To clarify this confusion, I develop a conceptual framework that focuses explicitly on the risk allocating function of alternative damage rules

${ }^{13}$ Not all courts and commentators have applauded the trend toward lost profits damages. See, for example, A. Lenobel, Inc. $v$ Senif, 252 AD 533, 300 NYS 226, 229-30 (1937); R.E. Davis Chemical Corp. v Diasonics, Inc., 826 F2d 678, 684 (7th Cir 1987); Charles Goetz and Robert E. Scott, Measuring Sellers' Damages: The Lost Profits Puzzle, 31 Stan L Rev 323 (1979). See also Morris G. Shanker, The Case for a Literal Reading of UCC Section 2708(2) (One Profit for the Reseller), 24 Case W Res L Rev 697 (1973); Comment, A Theoretical Postscript: Microeconomics and the Lost-Volume Seller, 24 Case W Res L Rev 712 (1973).

The polar issue of limiting damages to lost profits has received less attention in the literature. Most commentary approves of the modern trend. See sources cited in note 2 . The one recent article expressing skepticism about the wisdom of lost profit limitations is David Simon and Gerald A. Novack, Limiting the Buyer's Market Damages to Lost Profits: A Challenge to the Enforceability of Market Contracts, 92 Harv L Rev 1395 (1979).

14 To be sure, both market damages and lost profits are ex post in the sense that both measure what happened, not what the parties thought would happen. But market damages do reflect an ex ante perspective, as though, viewed from the time of contract, we did not know what would happen to these particular parties or how they would react to the exchange of market risk. 
in market contracts. The risk allocating function of market contracts is ubiquitous. ${ }^{15} \mathrm{~A}$ fixed-price contract functions as an option on the future supply of the goods at the contract price. Market damages reflect the ex ante value of the option. Application of a lost profits measure in those cases where the ex ante and ex post values diverge actually modifies the option contract by limiting or expanding the breacher's liability. Thus, the prevailing judicial approach to measuring damages has far-reaching feedback effects on the contractual allocation of risk.

In Part II, I advance the hypothesis that most parties to fixed price market contracts would prefer the risk allocation implicit in a market damages award. I test this hypothesis in two environments where market damages are thought to be inappropriate. In cases where market damages are seen as excessive because the injured party has laid off a portion of the contract risk, a lost profits rule functions as an implied limited-remedy provision. ${ }^{16}$ In the polar case where buyers breach contracts with volume sellers, a lost profits rule functions as an implied cancellation penalty. ${ }^{17}$ In both cases, a lost profits rule allocates market risks in an inefficient and unstable way. In a hypothetical bargain among sellers and buyers of goods traded in an available market, parties would generally prefer a contract term providing for market damages to one providing for lost profits.

In Part III, I use the risk allocation perspective as a guide for interpreting the damage rules specified in Article 2 of the Uniform Commercial Code. The UCC's drafters recognized both the risk allocation and measurement functions of damage rules. The various provisions of the UCC are best harmonized, therefore, by a presumption favoring the common law preference for market damages. I conclude that the lost profits "revolution" lacks support in

13 In fluctuating markets, fixed-price contracts serve principally to exchange the risk of market shifts. In the case of retail sales of durable goods, the fixed-price contract reserves a claim to a future supply of the goods. See Part I.B.3.

${ }^{16}$ I will argue that permitting a breacher to capture the benefits from the third-party contract motivates strategic breach. Furthermore, a lost profits measure triggered only by certain post-contract actions (such as the decision to lay off a portion of the risk) will necessarily skew the risk-bearing choices of the performing party. See text accompanying notes $71-74$.

17 Unhappily, the precise amount of this penalty depends on facts known only to the seller. Thus, I will argue that if a meaningful number of buyers value a "right of cancellation" (as is customary in the retailing of soft goods), adopting a lost profits measure as the standard legal rule in lost volume cases will inefficiently limit the seller's market. Most parties apprised of these circumstances would prefer to grant buyers a right of cancellation subject to payment of market damages (including incidental expenses) or to contract explicitly for fixed-sum deposits. See text accompanying notes 84-91. 
either the common law or contemporary statutory analysis, and that it clashes with the underlying objectives of most parties to market contracts. The legal system can best facilitate sales transactions by reinforcing the historic preference for market damages.

\section{The Function of Damage Rules in Market Contracts}

\section{A. The Lost Profits Puzzle Reconsidered}

1. A brief history: market damages versus lost profits.

The common law universally applied a market damages rule in breach of contract actions involving market-traded goods. Common law courts regarded any transactions between the injured party and third parties as irrelevant. ${ }^{18}$ Regardless of the economic gain the plaintiff might have received from full performance, the market value of the goods on the agreed date of delivery determined damages. As one commentator pointed out in an early treatise, market damages represented "the actual value of the goods at the time agreed upon for delivery," an amount fixed at that moment, regardless of whether the injured party later "keeps, sells, gives away, or destroys the goods." ${ }^{10}$ Thus, in its early development the rule of market damages measured loss without regard to the injured party's specific circumstances or intentions.

Market damages create no problems whenever the injured party can transform the particular contractual advantage into the market..$^{20}$ Assume that Seller contracts to sell market-traded goods to Buyer for $\$ 100$, delivery in six months. At the date of delivery, the market price has fallen to $\$ 50$ and Buyer breaches. If Seller has not hedged or laid off the contract with a third party, its loss is unquestionably measured by the $\$ 50$ contract-market differential. By combining the $\$ 50$ damages with the $\$ 50$ earned from reselling the contract goods at the lower market price, Seller receives the

\footnotetext{
18 See, for example, United States v Burton Coal Co., 273 US 337 (1927) (difference between $\$ 6.75$ contract price and $\$ 2.15$ market price allowed despite contract with third party supplier at \$6.30); Garfield \& Proctor Coal Co. v New York, N.H. \& H.R. Co., 248 Mass 502, 143 NE 312 (1924) (difference between $\$ 4.25$ contract price and $\$ 2$ market value allowed, although cost of production in plaintiff's mines from which he had to furnish the coal was \$3.10); Recent Decisions, 27 Colum L Rev 870, 877 (1927) (listing cases).

19 Theodore Sedgwick, 3 A Treatise on the Measure of Damages $\S 855$ at 1770 (Baker, Voorhis, 9th ed 1912) (emphasis in original).

${ }^{20}$ The relevance of market transformation was well understood at common law. See, for example, Spencer Kellogg \& Sons, Inc. v Providence Churning Co., 45 RI 180, 121 A 123, 124-25 (1923) (in action against purchaser for breach of contract for coconut oil, proper to instruct that cost of production was immaterial, since the seller was at liberty to purchase oil on the market to fulfill the contract).
} 
same economic benefit it would have enjoyed had Buyer accepted delivery.

But the injured party cannot always transform its contract rights into the market. Assume, for example, that before the date of performance, Seller enters into a contingent contract with a third-party supplier. The contract provides that if Seller supplies goods to Buyer, Seller must acquire them from Supplier at a fixed price of $\$ 80$. When Buyer defaults, Seller exercises its option not to acquire the goods from Supplier. Under these circumstances, market damages of $\$ 50$ result in a greater profit for Seller than the $\$ 20$ it would have earned if Buyer had accepted delivery and paid for the contract goods. Seller's supply contract has frozen its potential share of any future market fall and has released the balance of that market advantage to the remote supplier. ${ }^{21}$

Notwithstanding this apparent discrepancy between market damages and full performance compensation, most common law courts continued to award full market damages, holding that any third party contract was irrelevant in computing the injured party's loss. ${ }^{22}$ The rule became universally accepted in England and the Commonwealth countries following the decision in Rodocanachi, Sons \& Co. $v$ Milburn Brothers in $1886 .{ }^{23}$ In refusing to take account of a resale contract that appeared to limit the loss of a plaintiff buyer, the court announced: "If there is a market there is no occasion to have recourse to [lost profit modes] of estimating the value [of the contract]. The value will be the market value

${ }^{21}$ See Simon and Novack, 92 Harv L Rev at 1404 (cited in note 13). The problem arises only where the injured party is partially or entirely excused from the third-party contract. See note 5 . If the supplier/seller contract is not contingent, then the lost profits remedy will obviously harm Seller because it receives truncated damages from Buyer but is liable to Supplier for full market damages.

${ }^{22}$ Stebel $v$ United States, 69 F Supp 221, 223 (Ct Cl 1947) (resale contract does not limit market damages award); Tennessee Fertilizer Co. $v$ International Agr. Corp., 146 Tenn 451, 243 SW 81, 85 (1922) (market damages awarded rather than lost profits plus any sum owed to third party); Clinton Oil \& Mfg. Co. $v$ Carpenter, $113 \mathrm{SC} 10,101 \mathrm{SE} \mathrm{47,50}$ (1919) (resale contracts do not limit award of market damages); Floyd $v$ Mann, 146 Mich 356, 109 NW 679, 684 (1906) (same); and cases cited in note 18.

A minority of courts have held that the injured party should be limited to lost profits when it was fully protected against the breach by a contingency clause in the third-party contract. See Foss v Heineman, 144 Wis 146, 128 NW 881, 883-85 (1910) (injured party had no liability to third party because its contract was contingent). McCormick regarded this as the "better" view. McCormick, Damages $\S 175$ at 669 (cited in note 7).

${ }^{23} 18$ QBD 67 (1886). See also Williams Bros. v Ed T. Agius, Ltd., 1914 App Cas 510, 520 (Rodocanachi approved and followed by House of Lords). 
when the goods ought to have arrived. But the value is to be taken independently of any circumstances peculiar to the plaintiff."

It thus became well settled that, in an action for nondelivery or nonacceptance of goods under a contract of sale, the law would not take into account anything accidental as between the plaintiff and the defendant, such as an intermediate contract with a third party for the purchase or sale of the goods. ${ }^{25}$ The common law courts justified their adherence to market damages by focusing on the plaintiff's risk. Lord Esher stated in Rodocanachi:

It is admitted in this case that, if the plaintiff [buyers] had sold the goods for more than the market value before their arrival, they could not recover on the basis of that price but would be confined to the market price, because the circumstance that they had so sold the goods at a higher price would be an accidental circumstance as between themselves and the [defendants]; but it is said that, as they have sold for a price less than the market price, the market price is not to govern. . . . I think, that if the law were so, it would be very unjust. ${ }^{26}$

In other words, if the injured party bore the risk of an unfavorable fluctuation in the market, it should receive a favorable fluctuation when the market turned to its advantage. ${ }^{27}$

Early codifications of the law of sales retained the common law insistence on market damages whenever goods are traded in well-developed markets. The Uniform Sales Act, drafted by Samuel Williston, largely codified common law rules. ${ }^{28}$ Under the Sales Act, if an "available market" for the goods existed, then the contract-market differential determined damages unless special circumstances established a greater loss. ${ }^{28}$ As with the common law, the market damages rule applied under the Sales Act even when it placed the injured party in a better position than if the deal had been completed. In one case a seller agreed to supply the government with coal at a price of $\$ 6.75$ per ton from certain specified mines not owned by the seller. ${ }^{30}$ The seller made contracts with

$2418 \mathrm{QBD}$ at 76-77.

${ }^{2 s}$ Simon and Novack, 92 Harv L Rev at 1405-1412 (cited in note 13); Samuel Williston, 11 A Treatise on the Law of Contracts $\S 1388$ at 425 (Baker, Voorhis, 3d ed 1968).

${ }^{26} 18 \mathrm{QBD}$ at 77.

${ }^{27}$ Professor Farnsworth identifies this as the reciprocity principle. See E. Allan Farnsworth, Your Loss or My Gain? The Dilemma of the Disgorgement Principle in Breach of Contract, 94 Yale L J 1339, 1374 (1985).

${ }^{28}$ McCormick, Damages $\S 172$ at 657 (cited in note 7 ).

${ }^{29}$ Uniform Sales Act $\S \S 64(3), 67(3)$. The market damages test was also codified in the English Sale of Goods Act of 1894. Sale of Goods Act, 1894, 56 \& 57 Vict, ch 71, § 51(3).

${ }^{30}$ Burton Coal, 273 US at 338-39. 
these mines to furnish the coal for about $\$ 6.30$ per ton. After the market value had fallen to $\$ 2.15$ per ton, the government refused to take the coal. The seller in turn declined (apparently without liability) to take the coal from the mines. ${ }^{31}$ Applying the Sales Act, the Supreme Court awarded the seller full market damages of $\$ 4.60$ per ton even though the seller would have earned a profit of only 45 cents per ton had the government accepted the goods. ${ }^{32}$

In an even greater number of cases, market damages appeared to undercompensate the injured party significantly. Market damages often limited retail sellers of standard-priced goods to nominal or incidental damages for breach. This apparent anomaly supported a wider access to lost profits damages in cases involving "lost volume" sellers. ${ }^{33}$ These sellers contended that, although they did in fact resell the contract goods, the other buyer would have purchased anyway. Therefore, if the breaching buyer had fully performed the contract, the seller would have realized two profits from two sales. Because selling the goods to the second buyer produced only one profit for the seller, the breaching party ought to compensate for the lost profit in order to put the seller in the position it would have achieved had the buyer performed. ${ }^{34}$

The situations in which market damages seemed unable to implement the full performance principle led to revision of the damages rule. The initial revision of the Uniform Sales Act eliminated the "available market" standard which had limited the use of lost profits measures. Instead, the section provided that the measure of damages would be the difference between the contract price and the market price, "except that if the foregoing measure of damages is inadequate to put the seller in as good a position as performance would have done then the measure of damages is the profit the seller would have made from full performance by the buyer." ${ }^{35} \mathrm{Al}-$ though the draft did not include commentary to explain the

31 At trial the seller did not introduce any evidence that it was bound to take or pay for any of the coal ordered from the designated mines, and made no claim for damages suffered by the suppliers. Id at 339 .

${ }^{32}$ Id at 340-41. See also Garfield \& Proctor Coal Co., 143 NE at 312; Iron Trade Products Co. $v$ Wilkoff Co., $272 \mathrm{~Pa} \mathrm{172,116} \mathrm{A} 150$ (1922) (market damages awarded despite buyer's release from liability to third party purchaser).

ss See Stewart v Hansen, 62 Utah 281, 218 P 959, 961 (1923); Torkomian v Russell, 90 Conn 481, 97 A 760, 761-62 (1916). See also Electrical Products Corp. of Colorado v Mosko, 88 Colo 447, 297 P 991, 994 (1931) (lost profits analysis applied to lease for custom-built sign).

34 See Goetz and Scott, 31 Stan L Rev at 323 (cited in note 13).

35 Uniform Sales Act § 110 (Proposed Final Draft No. 1, 1944), in Elizabeth Kelly, ed, 2 Uniform Commercial Code Drafts 58 (Rothman, 1984) ("UCC Drafts"). 
change, a clear indication of the drafter's concerns appeared when the Uniform Revised Sales Act was incorporated into the 1949 draft of Article 2 of the UCC. The revised section became UCC $\S$ 2-708, and the Code drafters provided the following comment:

The provision of this section permitting recovery of expected profits where the standard measure of damages is inadequate, together with the new requirement that price actions may be sustained only where resale is impractical, are designed to eliminate the unfair and economically wasteful results arising under the older law when fixed price articles were involved. This section permits recovery of lost profits in all appropriate cases, which would include all standard priced goods. ${ }^{36}$

Following the adoption of the UCC, the attack on market damages has only intensified. Numerous commentators, ${ }^{37}$ now joined by many courts, ${ }^{38}$ assert that when market transformation is

${ }^{36}$ UCC § 2-708, Comment 2 (1949 draft) (emphasis added), in UCC Drafts at 251 (cited in note 35$)$.

${ }^{37}$ In addition to sources cited in note 9, see Ryden Anderson, Pitfalls for Sellers and Buyers Under the Market Formula of Section 2-708, 4 Rev Litig 251 (1985); William Schlosser, Damages for the Lost-Volume Seller: Does an Efficient Formula Already Exist?, 17 UCC L J 238 (1985); John A. Sebert, Remedies Under Article Two of the Uniform Commercial Code: An Agenda for Review, 130 U Pa L Rev 360 (1981); Note, Lost-Profits Damage Awards Under Uniform Commercial Code Section 2-708(2), 27 Stan L Rev 1109 (1985); Note, An Economic View of the UCC: Seller's Damage Measures and the Identification of the Lost-Volume Seller, 49 Albany L Rev 889 (1985); Note, Seller's Recovery of Lost Profits for Breach of a Sales Contract: Uniform Commercial Code § 2-708(2), $11 \mathrm{Wm}$ Mitchell L Rev 227 (1985).

${ }^{38}$ See Teradyne, Inc. $v$ Teledyne Industries, Inc., 676 F2d 865, 868 (1st Cir 1982) (buyer of transistor test system liable to volume seller for lost profits because market damages would be inadequate); Blair Int'l, Ltd. v LaBarge, Inc., 675 F2d 954, 960-61 (8th Cir 1982) (jobber entitled to lost profits because market damages inadequate); Comeq, Inc. $v$ Mitternight Boiler Works, Inc., 456 S2d 264 (Ala 1984) (seller, a middleman, entitled to lost profits in order to be in the same position as full performance); Neumiller Farms, Inc. $v$ Cornett, 368 S2d 272, 276-77 (Ala 1979) (unless there is both a market and an obligation for the aggrieved seller to enter it, market damages are functionally inadequate); Capital Steel Co., Inc. v Foster \& Creighton Co., 264 Ark 683, 574 SW2d 256, 259-60 (1978) (lost profits awarded to volume seller because $\S 1-106$ requires liberal remedies in order to achieve full performance compensation); Snyder v Herbert Greenbaum \& Assoc., Inc., 38 Md App 144, 380 A2d 618, 624-27 (1977) (buyer who cancelled contract for purchase and installation of carpet liable for lost profits because market damages inadequate); Distribu-Dor, Inc. $v$ Karadanis, 11 Cal App 3d 463, 90 Cal Rptr 231, 235-36 (1970) (middleman allowed to recover lost profits); and Coast Industries, Inc. v Noonan, 231 A2d 663, 665 (Conn App 1966) (also allowing lost profits damages to middleman).

For cases awarding lost profits damages to volume sellers, see, for example, Neri $v$ Retail Marine Corp., 30 NY2d 393, 285 NE2d 311, 314 (1972); Islamic Republic of Iran v Boeing Co., 771 F2d 1279, 1290 (9th Cir 1985); Tri-State Petroleum Corp. v Saber Energy, Inc., 845 F2d 575 (5th Cir 1988); Famous Knitwear Corp. v Drug Fair, Inc., 493 F2d 251, 
not feasible, the market damage measure often does not even closely approximate the economic loss suffered by the breach. Moreover, the economic loss sustained when the contract is not completed is precisely measured by the profits the injured party anticipated from the breached contract. Conventional wisdom argues that, rather than measuring losses by indirect and apparently inaccurate market damage measures, the common law and UCC preference for market damages should be abandoned in favor of a lost profits measure. ${ }^{39}$

\section{The contemporary debate.}

a) The lost volume case. Not all commentators have argued for the presumptive accuracy of lost profits measures. Contemporary debate focused initially on whether a lost profits rule in fact measures the contractual expectancy more accurately than market damages. ${ }^{40}$ In an earlier article, Charles Goetz and I suggested that determining potential gains and losses through a lost profits measure is far more difficult than had conventionally been assumed. ${ }^{41} \mathrm{We}$ argued that the evolving judicial presumption that the lost volume seller is entitled to full lost profits damages is unwarranted. Mere ability to supply additional volume in no way implies that such volume could have been supplied profitably. A lostvolume claim may be justified if sales to other buyers are unaffected by the breach because profitable volume then declines by the full amount of the breach. Conversely, a seller loses no volume (or, more properly, less than the full profits attributable to the breached contract) if the breach alters its cost and demand conditions so that supplying other buyers becomes newly profitable. In some cases, the seller may save the increasing costs of producing the contract goods for later delivery. Even when breach yields no cost savings, the buyer's breach may nonetheless expand the seller's market. Had the buyer elected to accept delivery and then resell the contract goods to a potential customer of the plaintiff seller, the buyer could have captured some (or perhaps all) of the volume for which the seller is claiming compensation. Breach

253-55 (4th Cir 1974); Nederlandse Draadindustrie NDI B.V. v Grand Pre-Stressed Corp., 466 F Supp 846, 853-54 (E D NY 1979); Van Ness Motors, Inc. v Vikram, 221 NJ Super 543, 535 A2d 510, 511 (1987).

${ }^{39}$ The standard attacks on the use of market damages are well summarized in White and Summers, 1 Uniform Commercial Code $\S \S 6-3$ to 6-4 and $\S \S 7-6$ to 7-14 (cited in note 9).

40 See sources cited in notes 9, 11 and 13 .

${ }^{41}$ See Goetz and Scott, 31 Stan L Rev at 323 (cited in note 13). 
removes this threat of competition from the breaching buyer, and to some extent expands the seller's market. ${ }^{42}$

The legal relevance of this analysis deserves emphasis. The UCC authorizes a lost profits award only when market damages are "inadequate to put the seller in as good a position as performance would have done. ..."43 If the breaching buyer can show that, had it "performed," it could thereafter have feasibly resold the unwanted goods to a potential customer of the seller, then the seller's sales volume after the breach would equal the volume after performance. ${ }^{44}$ Thus, if the appropriate comparison is between the seller's position with or without the breach once the buyer has decided not to keep the goods, the seller's actual volume will remain the same. This is not to say, however, that the seller has not suffered any economic loss. The breach costs the seller its expected volume, determined at the time of contract. The seller should be compensated for this lost expectancy. The question remains, however: how should the court determine this expectancy?

There have been important advances recently in the analysis of lost volume cases. Victor Goldberg, ${ }^{45}$ and Robert Cooter and Melvin Eisenberg, ${ }^{46}$ argue that retail sellers incur "selling costs" that they cannot save if the buyer fails to accept delivery. Cooter and Eisenberg focus on the method by which retail sales are made. Using a "fishing model" of business conduct, they argue that many retail sellers do not pursue buyers individually by adjusting prices. Rather, they "fish" for a number of buyers by holding prices constant and incurring predetermined selling costs (advertising, sales personnel, inventory maintenance, etc.). Substantial retailing costs are consumed in order to obtain contracts with an estimated "catch" of buyers. Thus, if any buyer refuses to accept delivery, a subsequent sale to another buyer will not recoup the amortized portion of those costs. ${ }^{47}$ Professor Goldberg refines this argument by suggesting that, in an imperfectly competitive environment, these retailing costs will be roughly equivalent to the seller's gross

42 This argument is developed in detail in id at 330-46. It was explicitly adopted in $R$. E. Davis Chemical Corp. v Diasonics, Inc., 826 F2d 678, 684 (7th Cir 1987).

${ }^{43}$ UCC § 2-708(2). Under the UCC, market damages pursuant to $\S 2-708(1)$ or $\S 2-706$ should generally be awarded except where they fail to put the seller in a situation as good as its post-performance position.

44 In other words, a presumption in favor of lost volume damages is based on the assumption that only the seller could have made the second sale. See A. Lenobel, Inc. $v$ Senif, 252 AD 583, 300 NYS 226, 229 (1937).

${ }^{45}$ Goldberg, $57 \mathrm{~S}$ Cal L Rev at 283 (cited in note 11).

${ }^{46}$ Cooter and Eisenberg, $73 \mathrm{Cal} \mathrm{L} \mathrm{Rev} \mathrm{at} 1434$ (cited in note 11).

${ }^{47}$ Id at $1455-59$. 
margin - the difference between wholesale and retail price. Since this is essentially the seller's "lost profits," Goldberg suggests that, at least for retail sellers, a lost profits award is a convenient proxy for uncompensated selling costs. ${ }^{48}$

Neither of these arguments is free from difficulty. ${ }^{49}$ Nevertheless, they mark an important shift in the focus of the debate from an ex post analysis of circumstances existing at the time for performance to an ex ante evaluation of expected gains and losses. Surprisingly, although the ex ante perspective is insightful, it has not yet resolved the debate over lost volume damages. The continuing uncertainty derives from the way commentators have framed the issue.

Although Goldberg and Cooter/Eisenberg characterize their analyses in terms of the lost volume debate, in reality their arguments do not concern lost volume at all. The fishing model tells a story about incidental damages, not lost profits. A volume seller using the fishing model of business conduct incurs, for each relevant period, fixed selling costs that are consumed in "catching" a given volume of buyers. A seller saves none of these costs when one buyer breaches. Thus, resale does not replace the lost selling efforts attributable to the breached contract. ${ }^{50}$ This seller requires an award of incidental damages equal to the selling costs attributable to the breached contract. ${ }^{51}$ The economic analysis has thus far sought to specify an accurate measure of the expected selling costs incurred by volume sellers. This question is highly complex and fact-specific. ${ }^{52}$ Moreover, courts frame the issue in terms of a dif-

48 Goldberg, $57 \mathrm{~S} \mathrm{Cal} \mathrm{L} \mathrm{Rev} \mathrm{at} \mathrm{292-94} \mathrm{(cited} \mathrm{in} \mathrm{note} \mathrm{11).}$

49 Cooter and Eisenberg comprehend well the relevant legal categories. Unfortunately, they develop classifications using terminology of their own invention. Placing their observations in the context of an ongoing debate is difficult. Goldberg's treatment is also insightful, but in conjoining selling costs with lost profits, he ignores the fact that a lost profits recovery under UCC $\S 2-708(2)$ includes in addition the recovery of amortized fixed overhead as well as incidental damages under $§ 2-710$.

so Fifty-five years ago, Charles McCormick anticipated both this argument and the rudiments of the fishing model conceptualization. See McCormick, Damages $\S 173$ at 661 (cited in note 7) (lost volume rule can be rationalized "as a case where there is no 'available,' that is, immediate, 'market,' but only an eventual market costing time and effort to capture").

${ }^{51}$ Under UCC \$ 2-710 incidental damages may be granted for "expenses . . incurred in the transportation, care and custody of goods after the buyer's breach, or in connection with return or resale of the goods or otherwise resulting from the breach."

${ }_{52}$ Establishing the loss suffered by a particular volume seller depends on several questions. Is the seller's market perfectly or imperfectly competitive? Does seller respond to changes in demand by adjusting prices or inventory? What is the probability that if buyer performed, he could resell to one of seller's customers? The answers turn on complex empirical realities, and are necessarily speculative. Predicting the seller's loss requires comparing 
ferent question: they ask which damage rule is better, assuming one must choose between lost profits and market damages. Unfortunately, the recent literature does not address this question systematically.

b) The limited remedy case. The debate over limiting damages to lost profits (as when the injured party has contracted with a third party prior to breach) has been no more conclusive. Perhaps the best illustration of the courts' confusion is the wellknown case of Nobs Chemical, U.S.A., Inc. v Koppers Co., Inc.. ${ }^{53}$ Koppers contracted to buy from Nobs Chemical 1,000 metric tons of cumene, a colorless oily hydrocarbon. After Nobs had contracted to fill the order from a Brazilian supplier, but before the time for performance, Koppers repudiated the contract. Nobs was able to obtain a release from its commitment to the supplier, and never paid for or obtained possession of the contract goods. The plaintiff-seller nevertheless argued that it should recover market damages measured by the $\$ 300,000$ difference between the contract price and the market price at the time for performance. ${ }^{54}$ The defendant-buyer, on the other hand, argued that the seller was entitled only to recover lost profits of $\$ 95,000$, representing the difference between the breached contract price and the fixed-price contract with the Brazilian supplier.

In limiting the seller to lost profits, the court virtually ignored the seemingly plain language of the $\mathrm{UCC}^{55}$ and the historic preference for market damages. Instead, it based its reasoning almost entirely on the primacy of the principle of full performance compensation. The court found any preference for market damages in the UCC language inconsistent with the principle that the "Act be liberally administered to the end that the aggrieved party be put in as good a position as if the other party had fully performed. ..."'s6 The court held that since the seller would only have earned a $\$ 95,000$ profit, it could only recover its actual economic loss. ${ }^{57}$

Nobs Chemical represents the clearest articulation of a "market transformation" gloss on the award of market damages. Under

\footnotetext{
the state of affairs that exists (after the breach) with one that never occurred (the seller's economic position had the buyer performed).

ss 616 F2d 212 (5th Cir 1980).

s4 See UCC \& 2-708(1).

so UCC \$ 2-708(2) provides for lost profits whenever the measure of damages in subsection (1) is "inadequate to put the seller in as good a position as performance would have done. ..." (emphasis added).

se UCC § 1-106.

${ }^{37} 616 \mathrm{~F} 2 \mathrm{~d}$ at 215 .
} 
the rationale of Nobs Chemical, market damages are only an appropriate measure when the injured party has the capacity to exploit the shift in market price at or after the time for performance by, for example, waiting until the time for performance to acquire the contract goods. Otherwise, an award of market damages will violate the full performance principle.

Academic commentary has generally supported the Nobs Chemical result as well as its reasoning. Using the time for performance as the point of reference, White and Summers have pointed out that the market damages rule disregards the possibility that a nonbreaching party may have reduced or avoided its loss by replacing the breached contract or, in the alternative, by selling off a portion of the market risk. ${ }^{58}$ Thus, they conclude that "perhaps the best explanation" of the market damages rule is that it is a "statutory liquidated damages clause, a breach inhibitor the payout of which need bear no close relation to plaintiff's actual loss." On the other hand, as others have noted, while the injured party may have lost (or gained) less than the market shift as matters turned out, it is also true that the breach foreclosed a contractual opportunity to make a profit on the market. ${ }^{60}$ The expected value of the lost opportunity (as differentiated from its value once exercised) is measured by the contract-market differential and not by the profits lost in any particular case.

The response to these arguments has been predictable. Confused by the complex arguments over damage measurement, many courts have retreated to general principles. An especially attractive focal point has been $\S 1-106$ of the UCC, which incorporates the full performance principle. Section 1-106 seemingly trumps the various arguments for market damages. Thus, the conclusion reached by most contemporary courts is that market damages should not be used where the award is more than the economic gain the injured party would have enjoyed had the goods been delivered and accepted. ${ }^{61}$

s8 White and Summers, 1 Uniform Commercial Code $\S 6-4$ at 293-95 and $\S 7-7$ at 349 56 (cited in note 9 ).

${ }^{80}$ Id at 295.

60 Simon and Novack, 92 Harv L Rev at 1419-20 (cited in note 13).

${ }^{81}$ See Nobs Chemical, 616 F2d at 212, 215-16; Allied Canners \& Packers, Inc. v Victor Packing Co., 162 Cal App 3d 905, 209 Cal Rptr 60, 66 (1984); H-W-H Cattle Co., Inc. v Schroeder, 767 F2d 437, 440 (8th Cir 1985); Coast Trading Co. v Cudahy Co., 592 F2d 1074, 1083 (9th Cir 1979); Union Carbide Corp v Consumers Power Co., 636 F Supp 1498, 1501 (E D Mich 1986); and American Metal Climax, Inc. v Essex Int'l, Inc., 16 UCC Rep 101, 11415 (S D NY 1974). But see Trans World Metals, Inc. v Southwire Co., 769 F2d 902, 908 (2d Cir 1985) (lost profits measure does not apply simply because contract-market differential exceeds economic loss). 
B. The Risk Allocating Function of Damage Rules

1. Reconstructing the concept of full performance compensation.

The preoccupation with ex post damage measurement in the debate over lost profits is symptomatic of an underlying problem: an unduly narrow conceptualization of contract performance. Conventional analysis considers performance under a sales contract only in terms of the ultimate exchange: delivery by the seller and payment of the contract price by the buyer. Because the economic gain that would have been earned from delivery and payment is the profit from the contract, it is tempting to assume that lost profits damages, at least in theory, always equal full performance compensation.

Unhappily, this conceptualization of contract performance is incomplete, and the assumption is false. In fact, the notion of contractual performance has no fixed or inherent meaning. The contract is not just an agreement for delivery, acceptance, and payment. It also contains an express or implied term specifying damages in case of nondelivery or nonacceptance. Contract performance requires either the exchange of goods for the contract price or the payment of an appropriate monetary substitute. In short, the damage remedy is itself a part of the contracted-for performance.

The choice between damage rules thus depends on how the parties have allocated the relevant market risks. If the risks and associated remedies are explicitly allocated in the contract, the exercise is straightforward. If not, the law must supply an appropriate default rule as an implied contract term. In both cases, determination of what economic advantage is protected by the contract must precede the necessarily narrower question of how to measure the damages for breach.

Viewing the question of damages as an ex ante contract term suggests that the post-performance position the injured party is entitled to claim depends on how the contract has assigned the risks of nondelivery or nonacceptance. Assume, for example, that Buyer and Seller enter into a fixed-price contract for the sale of goods in which they explicitly agree that Buyer has an option to cancel on or before the date of delivery upon payment of a $\$ 100$ cancellation charge. Obviously, "performance" in this contract does 
not just mean delivery of the goods and payment of the price. Rather, performance means delivery of the goods and payment of the price if the cancellation option is not exercised. No one would argue that Seller is entitled to lost volume profits if Buyer refuses to accept the goods on delivery. Seller's damages will be limited to the $\$ 100$ cancellation charge.

To be sure, this is a customized contract. Yet, the same principle holds for a contract in which the relevant damage and performance terms are implied. The prevailing custom in the retailing of soft goods, for instance, is that buyers may cancel before or shortly after accepting delivery. If Buyer exercises this cancellation privilege, no one would argue that Seller should receive lost volume profits. Custom has defined performance to include the implied right of cancellation. ${ }^{62}$

Finally, assume a contract where there is no custom, no explicit term, and Buyer once again refuses to take delivery. What position would Seller have occupied had Buyer "performed"? It is clear that Seller's damages cannot be determined before the contract performance is first specified. Whether lost profits or market damages should be granted the lost volume seller thus depends on whether a lenient or a harsh cancellation policy is implied as the legal default rule. The nature of the cancellation policy, in turn, depends on how the two parties allocate contract risks.

A similar analysis applies to the case where market damages seem to overcompensate. Assume that the contract explicitly provides that Buyer either accept delivery of the contract goods or pay the contract-market differential determined as of the date of delivery. Thereafter, Seller contracts to acquire the goods from a supplier at a price that will earn Seller a $\$ 50$ profit if the deal goes through. Upon breach, if the contract-market differential is $\$ 100$, Buyer cannot satisfy its contractual obligation by tendering only the $\$ 50$ profit Seller would have earned had the goods been accepted. Limiting damages to lost profits would deny Seller the benefit of its bargain by reallocating contract risks from Buyer to Seller. ${ }^{63}$ Similarly, in the more typical case where the contract is

62 The UCC implies as a state-supplied term any prevailing commercial practice in any recognizable class of transactions. See, for example, UCC § 1-205(2).

${ }^{\text {Bs }}$ One might argue that an explicit contract term providing for market damages in case of breach would be an invalid penalty. But a stipulated damages clause is enforceable as long as it represents a reasonable forecast of just compensation for the anticipated harm caused by the breach. Restatement of Contracts $\S 339(1)(\mathrm{a})$, Comment on Subsection (1) (1932); UCC § 2-718(1), Comment 1; Corbin, 5 Contracts $\S 1059$ (cited in note 7); McCormick, Damages $\S 149$ at 599-608 (cited in note 7). Furthermore, most courts assess the rea- 
silent, the choice between lost profits and market damages turns on whether this damage limitation is implied as the default rule.

In sum, the apparent dichotomy between market damages and full performance compensation is false. The alternative damage rules both measure the position the aggrieved party would have occupied upon performance, but from two different temporal perspectives. Lost profits reflect the injured party's ex post economic loss; they measure the value of the completed contract at the time of breach. Market damages, on the other hand, reliably measure the ex ante economic opportunities purchased by the contract. Both rules approximate full performance compensation. The question is whether the parties agreed to measure the value of the bargain ex ante rather than ex post.

\section{Fashioning majoritarian default rules.}

Damage rules allocate risks between contracting parties in much the same way as the many other default rules that govern contractual performance. Individual parties remain free to opt out and, within limits, to design their own damages rules. In evaluating which damage rules are "best," therefore, it is useful to identify the terms that the broadest number of parties would likely agree to if they had explicitly bargained out a remedial scheme. In the case of goods traded in well-established markets, it may be possible to deduce an optimal default rule (or at least to choose between lost profits and market damages) by asking what remedial terms would best facilitate the market transactions involved.

Once one understands the risk-allocating dimension of damage rules, the question of specifying an appropriate default rule becomes more tractable. In a world where Coasian assumptions of zero transactions costs hold, the damage rule is irrelevant because parties can and will negotiate around a suboptimal legal rule. But in a world of transactions costs anything can happen, and, absent substantial data on those costs, one cannot predict that any given rule is better than any other for any particular contracting parties. Surely, though, some rule for breach of contract is preferable to no

sonableness of the stipulated damage provision ex ante. See McCarthy $v$ Tally, $46 \mathrm{Cal} 2 \mathrm{~d}$ 577, 297 P2d 981, 987 (1956); Better Food Mkts. v American Dist. Tel. Co., 40 Cal 2d 179, 253 P2d 10, 14 (1953). An ex ante perspective measures the value of the opportunity, not the economic losses ex post. Any stipulated damages term must also pass a further test: the possible damages must be uncertain and difficult to estimate. However, the courts have seldom voided stipulated damages provisions solely because the damages were easy to estimate. For cases see McCormick, Damages $\S 148$ at 605-06. 
rule. If so, the law ought to adopt the rule that the broadest number of parties would adopt were transactions costs low enough for negotiators to tailor-make their own rules. ${ }^{64} \mathrm{~A}$ legal rule mirroring what most parties would adopt where transactions costs are low saves those parties the time, cost, and error inherent in negotiating rules and reducing them to writing. Where transactions costs are too high for parties to fashion their own rule, it may be normatively correct to provide them with the rule that they probably would have chosen for themselves had they been able to bargain. ${ }^{65}$

The norm of expanded choice justifies this preference for majoritarian default rules. Implied damages rules expand parties' choices by providing standardized and widely suitable contract terms to cover the contingency of breach. This norm implicitly presumes a neutral policy toward individualized agreements; the state has no desire to impose its default rules on unwilling parties. Viewed ex ante, therefore, individual parties lose nothing from the specification of majoritarian default rules because they remain free to design alternatives to the state's terms. Thus conceived, the underlying objective of contract law is to develop both generalized default rules and a menu of customized alternatives which, taken together, reduce transactions costs for both typical and atypical bargainers. ${ }^{68}$

3. Selecting damage rules that fit the function of market contracts.

Why do parties enter into a fixed-price contract for future delivery of goods that are traded on an open market? After all, one can always acquire the goods on the spot market at the prevailing price without contracting in advance. Consideration of this issue can clarify the choice between market damages and lost profits as alternative default rules. One answer, of course, is that the executory contract assures a reliable supply and thus smoothes out the inevitable distortions that may result from exclusive reliance on spot market purchases. But the buyer can fully achieve these pro-

64 This preference for majoritarian default rules does not undermine the selection of default rules designed to stimulate further borrowing. Certain default rules are set not because they represent the ultimate allocations preferred by most bargainers, but rather because they are best suited to inducing one party to share information with the other. See text accompanying notes 121-124.

${ }^{\circ}$ See Robert E. Scott, A Relational Theory of Default Rules for Commercial Contracts, 19 J Legal Stud 597, 606-13 (1990).

${ }^{68}$ Id at 607 . Only such an approach will support both instruments of contractual formation-generalization and particularization. 
duction efficiencies by contracting for future delivery of a specified quantity of goods at the then-prevailing market price.

What, then, motivates parties to negotiate a fixed contract price that may vary from the market price at the time for delivery? Most plausibly, the parties believe it is to their mutual advantage to exchange the risks of fluctuations in the market. If the buyer in Nobs Chemical only wanted a guaranteed supply of cumene, the parties would have agreed to allow the price to float. Before contracting, the seller bore the risk of a subsequent decline in the market price of cumene; the buyer bore the risk of an increase in the market price. The fixed-price contract effectively exchanges these risks. Thereafter, the seller bears the risk of price increases and, in turn, possesses the reciprocal opportunity to hold the buyer to the risk of a price decrease.

The seller may deal with the contract risk/opportunity in a variety of ways. It can lay off the risk (as did the seller in Nobs Chemical) by contracting to purchase the goods from a supplier at a fixed price. Such a fixed-price supply contract enables the seller to pool its risks by selling a portion of the contractual opportunity to the third-party supplier. Alternatively, the seller can choose to self-insure and bear the entire risk internally. In this case the seller can produce the goods itself or wait and purchase them on the spot market just before the contract delivery date. Presumably, the seller chooses a strategy for bearing the risk of price increases (and for exploiting its reciprocal rights against the buyer should the market decline) that maximizes its expected return over a range of similar contracts.

The risk of market price fluctuations is not the only benchmark for evaluating the remedial choices of parties to market contracts. There are also fixed-price contracts whose primary purpose is to shift the risk of fluctuations in supply. ${ }^{67}$ Many retail sellers are concerned about inventory management, and retail buyers want primarily to reserve a claim to a future supply of the goods. Here, contracts function as an option on the future supply of the goods at the contract price. This perspective suggests a hypothesis: to the extent that market contracts are options on the future market, then market damages will, in general, better serve the contractual purposes of the broadest number of bargainers. Market damages measure the expectancy ex ante, and thus reflect the value of the option; lost profits, on the other hand, measure losses ex post, and thus only reflect the value of the completed exchange.

${ }^{67}$ See the discussion of retail volume sales at text accompanying notes $40-52$. 


\section{The Effects of Alternative Damage Rules ON MARKET RISKS}

In this Part, I examine more precisely the effects of different damage rules on the allocation of risks in market contracts. The discussion will show that using the ex post lost profits measure in cases where there is an available market for the contract goods results in inefficient and unstable allocations of market risks. If lost profits are used to limit the risks of market price fluctuations, the performing party is motivated to adopt an inefficient production strategy, while the breaching party is induced to breach opportunistically. The resulting instability would motivate most commercial parties either to choose an ex ante market damages measure in the event of breach or to negotiate explicitly for a more effective mechanism for limiting damages.

When lost profits are assessed against buyers who cancel contracts with volume sellers, the damage rule has a similarly distorting effect. Because it measures losses ex post, a lost profits award increases the buyer's liability unpredictably. A contract term imposing an uncertain penalty on buyers who cancel reduces the value of the contract to the buyer and inefficiently reduces the seller's market. Assuming any sizable number of customers value the privilege of cancellation, most volume sellers of market traded goods would be motivated to expand their market by providing a more forgiving, and more certain, cancellation provision. Market damages best implement this strategy.

\section{A. Lost Profits as a Remedy Limitation}

A number of recent cases reflect the trend toward using lost profits damages to limit market-based recoveries. ${ }^{68}$ To date, however, there has been no discussion of how commercial parties might respond to the emerging lost profits rule. Viewed ex ante, the lost profits rule is an implied contract term that limits the breaching party's market risk whenever the injured party has laid off a portion of the contractual risk with a third party. The key issue, therefore, is whether the rule allocates these market risks efficiently. To evaluate this question, consider the facts of Nobs Chemical in greater detail. Nobs contracted to sell 1,000 metric tons of cumene to Koppers at a fixed price of $\$ 540,000$. Nobs ar-

\footnotetext{
${ }^{68}$ See cases cited in note 22 .
} 
ranged to acquire the cumene in Brazil for $\$ 400$ per ton and to expend $\$ 45$ per ton in transportation costs, for a total expense of $\$ 445,000$. Koppers breached the contract when the market value of cumene dropped to around $\$ 220$ per ton at the time of delivery. Nobs was able to cancel the Koppers order with its supplier, although it lost its volume discount and had to pay an additional $\$ 25$ per ton on the balance of its order for other customers. At trial, therefore, the court confronted the choice between market damages of $\$ 320,000$ and the $\$ 95,000$ profit that, as matters turned out, the seller would have earned had the buyer accepted delivery and paid the contract price. ${ }^{69}$

The argument for limiting market damages to lost profits in this case is straightforward. Once the seller contracted with the Brazilian supplier, the shift in market price no longer affected the seller's costs, and thus an unlimited market damages award no longer bore any relationship to what would have been the seller's position had the contract been performed. But, as asserted above, a fixed-price contract is an option on the future market price. Market damages protect the value of the option, not the value of the completed performance. Thus, the issue turns on which economic advantage the contract protects. If parties to market contracts bargained over breach terms, would they endorse a lost profits limitation on market damages when the injured party lays off the contract risk with a third party?

The answer depends on the effects of such a limited remedy provision. In essence, the buyer has the unilateral option, by deciding to breach, to buy the seller's contract rights with the third party at zero cost. This, in turn, makes the choice of laying off the contract less valuable to the seller. ${ }^{70}$ The breaching buyer is a less attractive co-insurer than the third party supplier because, as the facts in Nobs Chemical suggest, breach invites the buyer to engage in strategic maneuvers designed to reallocate the original contract risks. ${ }^{71}$

68 616 F2d at 214.

${ }^{70}$ The option to breach also makes the choice of laying off the contract less valuable to the supplier, thus making it more difficult for the seller to hedge. This result leads to another argument in favor of market damages: most suppliers would presumably insist that the seller pay over that portion of any damages award that represents the difference between the supplier's cost and the price of the supply contract. Thus a market damages rule makes it easier for a seller to cancel its supply contract as well as to enter into it.

${ }^{71}$ Only imperfect rules that reflect compromise can establish and enforce the performance obligations of both parties. Moreover, the parties to executory contracts receive advance compensation in the form of premiums and discounts to bear any future costs that may arise. Tensions result when the price of traded goods (such as the cumene in Nobs 
Reallocation of contract risks is inevitable if the seller must bear uncompensated breach costs. These costs include the nonreimbursement of attorneys' fees as well as prejudgment interest awards below the market rate of interest. ${ }^{72}$ The buyer can exploit the seller's vulnerability to uncompensated costs by increasing the seller's collection costs. The recent cases limiting plaintiffs to lost profits illustrate this point. In Nobs Chemical the seller had to pay a $\$ 25$ per ton premium on cumene ordered for other customers as the "price" of cancelling the buyer's order. The buyer successfully denied responsibility for this sum on the grounds that it represented unrecompensable consequential damages. ${ }^{73}$

The problem with using lost profits to limit damages lies in the fact that the limitation applies only when the seller elects to contract with another supplier before the date of performance. If the buyer can, at its option, appropriate this contract, the seller bears the additional costs of dealing with the breaching buyer. Future sellers will anticipate these costs and make inefficient adjustments. One alternative is for sellers to increase the price to include a premium for the "insurance" being provided the buyer through the lost profits damage rule. But the insurance will cost more than its value to the buyer because the lost profits rule systematically skews the seller's incentives. The seller can secure the full benefit of the opportunity embodied in the fixed-price contract by electing not to contract with another supplier. The increased costs of dealing with the breaching buyer provide sellers additional incentives to wait and purchase goods on the spot market shortly before the date of performance. Whenever this decision is a less efficient method of production than sharing the risks with another supplier, the expected value of the contractual relationship is reduced..$^{74}$

Chemical) changes unexpectedly, giving the adversely affected party a strong incentive to chisel on his performance obligation. He may evade responsibility by contesting facts, exploiting arguably ambiguous terms, or refusing to provide full compensation upon breach. See generally Charles Goetz and Robert E. Scott, The Mitigation Principle: Toward a General Theory of Contractual Obligation, 69 Va L Rev 967, 977-78 (1983).

${ }^{72}$ One can best understand the injured party's dilemma by viewing breach as an involuntary loan equal to the amount of the ultimate damage bill. If the amount of the loan and the costs of credit are difficult to prove, the breaching party will always be able to shift some of these costs to the non-breacher because the non-breacher's collection costs are not recoverable. Thus, the optimal settlement point will always fall below the true damages owed.

${ }^{73} 616 \mathrm{~F} 2 \mathrm{~d}$ at 216 . The court also declined to characterize the $\$ 75,000$ lost discount as incidental damages compensable under UCC § 2-710. It held that § 2-710 was intended to cover only those expenses incurred by the seller after breach and occasioned by the seller's need to care for and dispose of the breached goods.

74 If the seller were an integrated firm (that is, its own supplier), its damages would equal market damages. If the seller were not integrated, it presumably could allocate part of 
The Nobs Chemical rule also encourages inefficient behavioral adjustments by the breaching buyer. Ideally, the buyer should breach only when it determines that the seller is better able to salvage the broken contract (such as by reselling the goods on the market). The decision to breach rather than perform and bear the resulting losses internally represents the buyer's cry for help: a request that the seller salvage the broken contract and send the buyer the damage bill. Viewed expectationally, both parties would prefer that the buyer only breach when it believes that the seller enjoys such an advantage. By deterring breach except when the seller has the comparative advantage in salvaging the contract, the parties can reduce the joint costs of bearing market risks, thus enhancing the value of the contractual opportunity for both. ${ }^{75}$ The unfortunate effect of the Nobs Chemical rule is to encourage buyers to breach opportunistically. Only by breaching can a buyer capture the benefits of the third party contract and share a portion of the resulting market advantage. Predictably, some buyers will breach in order to obtain the insurance benefits of the damage rule even in instances where (but for the damage limitation) the buyers enjoy the comparative advantage in minimizing the costs of salvaging the now regretted contract.

The rule limiting damages to lost profits creates instability. In a case such as Nobs Chemical, most sellers would prefer to supply a product that does not include an inefficient type of insurance, one that requires buyers to know a lot about the production process in order to determine whether they are getting their money's worth. The analysis applies with equal force to the analogous cases where plaintiff buyers who have contracted to resell to third parties have recovered only lost profits damages in actions against breaching sellers. ${ }^{76}$ In either case, the lost profits rule gives the breacher serendipitous reductions in the risk of price fluctuations. But it is hard to price those reductions ex ante. The serendipitous quality has a distorting effect on how the non-breacher bears risks which, in turn, causes unnecessary increases in production costs.

its own damages from the buyer to compensate the supplier for the supplier's loss. The lost profits argument overlooks the possibility of a separate bargain between the supplier and the seller. An important point follows: lost profits damages punish the seller for not being an integrated firm, and consequently deter efficient out-sourcing of supply.

${ }^{75}$ See Robert E. Scott and Douglas L. Leslie, Contract Law and Theory 723-26 (Michie, 1988).

${ }^{76}$ See Allied Canners, 209 Cal Rptr 60, H-W-H Cattle Co., 767 F2d 437, and discussion of buyers' breaches in text accompanying notes 6-11. 
Why, then, should we assume that the market damages remedy encourages superior decisions about how to bear the risk of price fluctuations? The answer lies in the parties' enhanced ability to evaluate the price of "the product" at the time of contract, and their ability thereafter to select production strategies irrespective of the prospect of the other's breach. Whenever a significant motivation for a fixed-price contract is to allocate the risk of price fluctuations, a market damages measure will induce more efficient risk-bearing behavior by the non-breaching party. A lost profits rule cannot retain these efficiencies. The reason is simple. Under a lost profits rule, there are two different contracts being offered for the same price. In one, a breacher's liability is limited (where the seller lays off the contract with a third party). In the other, it is not (where the seller produces the goods itself or acquires them on the spot market). The lost profits rule is not an equilibrium contract term because the rule treats these two contracts as equivalent when, in fact, they are not.

Once one visualizes a product as a combination of the goods plus certain legal rights and remedies, it makes no sense to think that parties would prefer a product (the damage limitation) whose value depends on conditions they are unable to observe except at great cost. The argument for limiting damages to lost profits seeks to measure damages by comparing the product before the judicial decision with the same product after the new damage rule is announced. The flaw in the analysis is that if the lost profits remedy were known in advance, it would change the price at which the product was sold. When the principal product is the sale of an option on the futures market, parties will prefer a damage measure that fixes the means of valuing the option at the time of contract to one that determines the value of the bargain at the time of performance.

\section{B. Rethinking the Lost Volume Problem: Lost Profits as a Cancellation Penalty}

Consider now the paradigmatic lost volume case in which economic loss may systematically exceed the traditional market damages award. Whether the award of traditional market damages will be "inadequate" depends on many complex factors. But the discussion above illustrates several clarifying points. First, it is virtually impossible to know when a seller has lost actual volume because of a breach. Sellers who react to changes in demand by adjusting prices will typically be able to replace contract losses on 
the spot market. ${ }^{77}$ Volume sellers who use the fishing model of business conduct (putting out a predetermined quantity of inventory at a fixed price) will lose an anticipated sale because of the breach. However, under these selling conditions, the breaching buyer can plausibly claim that the sale would have been lost even had the buyer performed and thereafter resold the goods to a potential customer of the seller. ${ }^{78}$ In either case, therefore, the buyer's choice to perform or breach will not affect the seller's $a c$ tual volume.

In short, the focus on lost volume is a red herring. What both sellers "lose" is an expected volume (at an expected price) determined as of the time of contract. The issue, then, is to determine the economic loss attributable to that lost expectancy. This loss will in all cases be equal to the fluctuation in market price together with any of the selling costs attributable to the breached contract.

Traditional market damages will inadequately protect the seller's expectancy in some cases. The distortion does not result from the inadequacy of the market measure per se, but from the tendency of courts to limit incidental damages to the seller's postbreach reliance costs. ${ }^{79}$ This limitation is appropriate for the pro-

77 The seller can resell on the spot market whenever he fishes for spot purchases individually by adjusting the price at which the goods are offered for sale. See Cooter and Eisenberg, $73 \mathrm{Cal} \mathrm{L} \mathrm{Rev} \mathrm{at} \mathrm{1451-55} \mathrm{(cited} \mathrm{in} \mathrm{note} \mathrm{11).} \mathrm{The} \mathrm{resale} \mathrm{opportunity} \mathrm{does} \mathrm{not} \mathrm{depend} \mathrm{on}$ whether the seller is operating under conditions of increasing marginal costs. (The marginal costs savings, if any, merely affect the amount of offset to be applied against the contract price/resale price differential.) The seller may recover such reselling costs as incidental damages. "[C]osts otherwise resulting from the breach" under UCC § 2-710 should also include any price reductions on other spot sales stemming from an inability to price-discriminate. However, the courts may not allow such costs under traditional interpretations of UCC $\S 2$ 710. If they do not, then a market damages award will not fully compensate this seller for his economic loss.

${ }^{78}$ The fishing model assumes that the seller engages in predetermined selling efforts to catch a given number of buyers at a fixed price. Assume that a seller sets out inventory sufficient to catch 20 buyers. After negotiating a contract for one unit, the defendant buyer decides that he no longer wants the contract goods. At this point, the buyer can "perform" by accepting delivery, paying the contract price, and then offering the goods to a potential customer of the seller. Alternatively, the buyer can breach and pay the seller to resell for him. Although the parties may well have different salvaging costs, the seller's actual sales volume in both cases is 19 units.

If the seller operates in a thick market (one with many buyers and sellers), it is more difficult for a buyer to argue that the resale customer would have purchased from the plaintiff seller. However, in such a case the fishing model becomes as implausible as the seller's claim that he could not resell the breached goods to another buyer.

79 Section 2-710 of the UCC defines incidental damages as "any commercially reasonable charges, expenses or commissions incurred in . . . connection with return or resale of the goods or otherwise resulting from the breach." The official comment to $\S 2-710$ reinforces the drafters' purpose to reimburse "expenses reasonably incurred [by a seller] as a result of the buyer's breach." 
totypical fixed-price contract, such as that found in Nobs Chemical, whose primary purpose is to allocate the risk of market shifts. But certain fixed-price contracts-such as the retail sale of standard-priced goods-only incidentally allocate market shifts. ${ }^{80}$ Their primary function is to reserve for the consumer a place in a limited queue. In this case, more of the seller's costs go to "maintain the queue." Such a seller should recover not only the market shift, but also incidental damages equal to the amortized portion of the total selling costs consumed in fishing for buyers in the relevant period. ${ }^{81}$

The familiar case of Neri $v$ Retail Marine Corp.$^{82}$ provides a useful framework for reexamining the lost volume problem. Retail Marine, a dealer in marine equipment and supplies, contracted to sell a new boat to Neri for $\$ 12,500$. Marine then ordered and received the boat from its supplier. Six days after the agreement Neri breached. Four months later, Marine sold the boat to another buyer for the same price. When Neri sued to recover his down payment, Marine counterclaimed for lost profits of $\$ 2,500$ under UCC $\S 2-708(2)$, arguing that absent Neri's default it would have earned two profits rather than one. The New York Court of Appeals sustained Marine's lost volume claim, holding that " $[t]$ he conclusion is clear from the record-indeed with mathematical certainty-that '[market damages are] inadequate to put the seller in as good a position as performance' ... and hence ... the seller is entitled to its [profit]. . .."8s

Most courts have interpreted this provision narrowly, to "cover only those expenses incurred by the seller after the breach." Nobs Chemical, 616 F2d at 216. See also Neri $v$ Retail Marine Corp., 30 NY2d 393, 285 NE2d 311, 315 (1972); Harlow \& Jones, Inc. v Advance Steel Co., 424 F Supp 770, 778 (E D Mich 1976). Therefore, courts generally do not award post-contract reliance costs, even where the breach enhances them. See Industrial Circuits Co. $v$ Terminal Communications, Inc., 26 NC App 536, 216 SE2d 919, 922 (1975) ("bill back" charges which resulted when buyer failed to order a certain quantity not allowed).

${ }^{80}$ The market price of durable goods does not fluctuate substantially, at least not over the short period of retail purchase agreements.

${ }^{81}$ Similarly, a seller who must adjust prices on all its spot sales in order to resell the contract goods should properly recover the price discounts as incidental damages.

In theory, the breacher should pay all the marginal selling costs that the business incurred expectationally in dealing with him. This point is the link to the frequent discussion in the lost volume cases of the seller's unused capacity. The breacher is properly responsible for all the capacity-enhancing costs attributable to the broken contract. As long as the breaching buyer pays his fair share of overhead expenses, the seller should be indifferent. But courts have traditionally allowed only out-of-pocket reliance costs, rather than expected reliance costs.

${ }^{82} 30$ NY2d 393, 285 NE2d 311 (1972).

8s Id at 314 (quoting UCC § 2-708(2)). 
Much commentary has addressed the question of whether the Neri rule accurately measures the damages suffered by lost volume sellers ${ }^{84} \mathrm{I}$ focus instead on the more fundamental question: what damage rule would more parties prefer?

The impetus for lost profits damages derives from the realization that market damages may not fully compensate the volume seller for its lost expectancy. Unless courts allow such sellers to recover selling costs consumed by the breacher in negotiating the contract, an award of market damages will be inadequate. The key to understanding the lost volume problem lies in the realization that lost profit awards err in the opposite direction. Consider the actions of sellers such as Retail Marine. If Retail Marine follows the fishing model of business conduct, it sets out a predetermined inventory of boats, invests in a preset level of selling activity, and hopes to generate $\mathrm{X}$ volume of sales over the relevant period. Experience also teaches Retail Marine that some statistically probable number of buyers $(\mathrm{Y})$ will change their minds and either breach or resell the goods. The seller's expectation following a contract with any buyer takes into account this probability. The seller's market is not total contracts (X), but rather total contracts less those buyers who change their minds (X minus Y). Since the court bases lost profits damages on its estimate of total contracts, the award provides more than the seller expects.

Consider again Goldberg's argument that since the gross margin of a retail seller in a competitive market will be expended in selling efforts, lost profits are a useful proxy for nonsalvageable selling costs. This argument conflates expected reliance on total contracts obtained with expected reliance on total sales completed. It is true that the "fishing" costs of getting buyers "on the hook" are consumed and thus nonsalvageable, but these costs do not equal the entire margin between wholesale price and contract price. If total sales are less than total contracts, then activities necessary to complete the sale eat up some portion of the seller's margin. These "completion" costs-such as delivery and product preparation-are incurred only for buyers who actually go through with the deal. Anticipating this probability, the seller will reduce its investment in contract completion. Furthermore, in addition to marginal "completion" costs, the non-marginal or fixed overhead costs-such as the building-are also not properly attributed to the breaching buyer because he does not consume or exhaust that

\footnotetext{
84 See sources cited in notes 9,11 , and 13 .
} 
resource. A lost profits award will thus overcompensate the volume seller because the buyer's breach does not consume significant retailing costs. ${ }^{85}$

Recognizing that both alternatives deviate from the ideal clarifies the function of the damage rule in contracts with volume sellers. Market damages and lost profits provide alternative mechanisms for allocating the risk of cancellation. Suppose a seller decides to market a product for which many consumers are likely to change their minds before delivery. The seller can choose either to market the product at a high price with a lenient cancellation policy, or at a lower price with a harsher cancellation policy ${ }^{86} \mathrm{Mar}-$ ket damages implement the former choice. The right of cancellation reflected in the market damages rule functions as an insurance policy purchased by the buyer as part of the contractual product.

A lost profits rule, on the other hand, functions as a cancellation penalty, increasing the costs and thus reducing the risk of breach. Obviously, at the time of performance, all sellers would prefer additional security against buyers' breaches. But contractual security must also be written into the contract, either expressly or by implication. A change in the damage rule from market damages to lost profits reduces the value of the contractual product because it increases the costs for buyers who wish to cancel the contract. Reducing product quality leads, in turn, to either a reduction in price or a reduction in the seller's market. One cannot determine a priori whether such a change would maximize profits. Common observation tells us that in many industries, sellers offer a product that includes a right of cancellation or return. In others, security deposits are commonplace. But this reconceptualization does invite a more careful examination of the relevant issue in lost volume cases: how would parties allocate the risk of cancellation?

Suppose that Retail Marine must choose between two contracts for marketing its boats: Contract A, with a potentially undercompensatory market damages rule, or Contract $\mathrm{B}$, specifying full recovery of overcompensatory lost profits. Assume further that Retail Marine operates under the following market conditions: (1) a thick market with many sellers, ${ }^{87}(2)$ some consumers who value

8s In our earlier article, Goetz and I assumed unrealistically that the seller's overhead includes no marginal costs. Equally implausibly, Goldberg assumes that the seller dedicates all overhead costs to marginal selling efforts. Health spas provide a good example of a retail industry with high fixed and completion costs relative to selling costs.

so The airline industry, which typically pairs a high fare with a lax cancellation policy and a low fare with a stringent one, offers a good example of this approach.

87 This condition encompasses both perfectly competitive and imperfectly competitive 
the right to cancel the contract at its cost to Marine; ${ }^{88}$ and (3) unexploited economies of scale in its production function. Contract A, with a more attractive right of cancellation (the market damages rule), permits Marine to increase its market by offering to sell goods to consumers who value the right to change their minds. Contract A increases the average volume of sales at any particular price. Marine is thus able to amortize its fixed costs over more consumers. This lowers Marine's average total costs and its price for everybody, those who exercise the cancellation privilege and those who do not. So long as the reductions in price are greater than the incremental costs of the market damages rule (the marginal costs of selling to additional buyers and the uncompensated selling costs for those buyers who breach), Contract $A$, with the more attractive cancellation feature, provides an unambiguous benefit for the parties to share.

Moreover, Marine would probably prefer to market its boats under Contract $\mathrm{A}$ even if it operated as a price monopolist in a thin market with few sellers. As a price monopolist, Marine can find its profit-maximizing quantity by adjusting price rather than product attributes. The monopolist need not sell cancellation insurance to attract the profit-maximizing number of consumers. Marine would still prefer Contract A because, as a monopolist, Marine prefers not to have a competitor who will "spoil" its market. The harsh cancellation policy induces a buyer who changes his mind nevertheless to accept delivery and then resell the contract goods.

A thin market with few sellers is the most plausible environment for a buyer to capture another customer of the seller. Contract B magnifies this market spoilage effect because a lost profits rule encourages inefficient self-help salvage decisions by buyers. The lost profits rule motivates the buyer to take delivery and then resell whenever the selling costs are less than the lost profits the buyer would otherwise have to pay. This incentive remains even

markets, including spatial monopolies of the kind typically associated with retail sales of brand-name products.

88 The problem of lost volume is analogous to any problem of the joint production of goods. People who want to change their minds are buying one product, and people who don't are buying a different product. The right of cancellation should, therefore, sell at cost in a competitive market. Thus, where there are fixed overhead costs but no marginal overhead costs (as with a retailer opening up a store), it costs nothing to provide the privilege of cancellation or return. In equilibrium, such a market will still generate a positive wholesale/ retail spread because the retailer must recover all the fixed costs (including the store opening) from consumers. But to award those costs as damages against a cancelling buyer would be a penalty. 
where the seller could salvage the now regretted contract at less cost. $^{89}$ Moreover, the prospect of obtaining a lost profits recovery will skew the seller's salvaging incentives. If a buyer breaches under Contract $\mathrm{B}$, the seller is motivated by the prospect of lost profits damages to hold the goods in inventory until the next fishing period even where an unanticipated resale opportunity materializes. $^{90}$ The overcompensatory lost profits rule thus makes both buyer and seller worse off and reduces the expected value of the contract.

In sum, under plausible assumptions, most volume sellers in a competitive environment would prefer a market damages default rule because this rule permits a seller to expand its volume and lower its price. A volume seller who operates as a price monopolist would still prefer the market damages rule because the monopolist prefers not to have a competitive fringe. To be sure, the desirability of packaging the retail product with a right of cancellation depends on the presence of consumers who would pay for the cancellation privilege. Nevertheless, the evidence of customary rights of cancellation in many environments suggests that these empirical conditions are common. ${ }^{91}$

In retrospect, the lost volume story can be understood perhaps as a predictable reaction to changes in retailing practices throughout the twentieth century. When common law courts applying a

${ }^{89}$ An example will illustrate the inefficiency of lost profits as a rule for directing salvage decisions. Assume Seller can prove estimated profits on total contracts of $\$ 2,000$ per contract. The "profit" consists of $\$ 1,000$ in expected marginal selling costs, $\$ 500$ in amortized fixed costs, and $\$ 500$ in expected marginal "completion" costs. Should Buyer resell himself, his salvaging costs are $\$ 2,250$. If buyer were to breach under a lost profits rule, Seller would recover lost profits of $\$ 2,000$, plus $\$ 500$ in out-of-pocket completion costs as recoverable incidental damages. Absent renegotiation of the inefficient damage rule, Buyer will choose instead to perform and resell for $\$ 2,250$ even though both parties would be better off if Seller were to agree to salvage the contract for $\$ 1,500$ (its total marginal expenditures in reselling).

so It would be nearly impossible for a buyer to rebut the seller's prima facie case for lost profits even when the breaching buyer did not fully consume the seller's gross margin. A lost profits award to a volume seller undermines the mitigation principle. It reduces the value of the contractual opportunity for both parties, because a buyer who anticipates bearing excess costs will presumably negotiate for a more costly return promise to compensate for these inflated costs. Both parties benefit if they agree in advance to provisions that reduce expected future costs. See Goetz and Scott, $69 \mathrm{Va}$ L Rev at 972-73 (cited in note 71).

${ }^{91}$ The optimal strategy for a boat seller such as Retail Marine may be to segment the market, by selling some boats without a lost profits contract (that is, with no penalty for cancellation) for a higher price and others with a market damages rule for a lower price. If this strategy is sometimes optimal, it supports the general preference for market damages as the background rule, because the market damages rule offers parties the cheaper route of opting out with a fixed fee deposit rather than custom designing a contract for buyers who value the right to cancel. See note 88 . 
market damages rule did not recognize the pre-breach selling expenses that retail sellers incur, they denied such sellers the full benefit of their bargain. Those selling costs became fixed in anticipation of the seller making X plus 1 sales, and could not be saved if instead the seller only made X sales. Moreover, it is plausible to assume that more selling costs became fixed as retail practices changed, particularly through use of increasingly large inventories. At some point, courts and commentators translated this intuition into "volume" as the means of distributing overhead. In fact, the volume seller does not lose a sale; rather, he loses the costs of hooking a prospect.

Understanding how the analysis evolved also leads to a sharper understanding of how it went astray. The error in the conventional lost volume argument is the assumption that the seller's expected volume equals the total number of contracts rather than the number reflecting expected cancellations and buyers' resales. The seller is thus overcompensated if a lost profits award enforces, after the fact, the contracted-for volume without adjusting for buyers' resales and buyers' returns. Focusing on expected volume tells us that as long as the buyer pays his fair share of the overhead expenses, the seller would be indifferent if the buyer exercised a cancellation privilege. In general, an ex ante damage measure will better approximate the value of that expectancy than will the ex post perspective of a lost profits award.

\section{Measuring Damages for Breach of Market Contracts}

The preceding discussion supports the common law preference for market damages when an available market for the contract goods exists. A market damages award is a superior default rule even when it deviates from ex post economic losses. In those instances, the market damages rule functions expectationally, guaranteeing the injured party the value of the other's performance as measured from the time of contract. In this Part, I examine whether the case for market damages can be harmonized with the remedial scheme of the Uniform Commercial Code.

\section{A. The Relationship Between the Risk Allocating and the Measurement Functions of Damage Rules}

One must define the bargain before selecting among alternative rules for measuring the loss of bargain. When market damages and lost profits diverge ex post, they are not alternatives. Rather, they are functionally different contract terms with different risk 
implications. The two mechanisms do not diverge, however, when the injured party can transform its internal costs and revenues by either purchasing or selling contract goods on the market at or after the time for performance. If the injured party's post-contract actions do not affect access to the market, ex ante losses equal ex post losses. Thus, from either perspective the injured party ends up in the same economic position he would have enjoyed had the goods been accepted and paid for. ${ }^{92}$ This case offers no a priori reason to prefer one alternative over the other. Rather, the choice among equivalents turns on a systemic question: which of these measures minimizes the costs of enforcing market contracts?

Two factors determine enforcement costs: the litigation costs of proving actual losses, and the error costs of selecting a damages measure that imprecisely mirrors the underlying objective of full performance compensation..$^{93} \mathrm{~A}$ procedurally optimal measure of damages minimizes the sum of these two costs. In other words, the most efficient damages measure offers the cost-minimizing balance between clarity and accuracy. This perspective reveals the error in condemning market damages because the rule only measures the expectancy indirectly, while lost profits do so precisely. ${ }^{94}$ In the case of lost profits, increased litigation costs offset the theoretical accuracy of the measure. Lost profits awards require proof of many facts concerning the nature of the seller's cost and market conditions. Obtaining these facts can be extremely costly. Thus, the greater litigation costs of proving lost profits will often exceed the approximation of economic losses achieved by using easily verifiable market equivalents. ${ }^{95}$

92 The injured party receives "lost profits" in every case. The risk allocation question, then, is whether to determine those lost profits ex ante, at the time of contract, or ex post, at the time of breach. If market transformation is feasible at the time of breach, the only question is one of measurement. If the plaintiff seller resells the contract goods on the market, then the sum of the market price, the market damages, and the seller's cost will equal the profits lost by the breach. Alternatively, the seller can establish the identical loss by showing the changes in estimated costs and revenues caused by the breach.

93 The clearer the substantive damage rule, the easier it is to enforce. The primary cost of a clear rule is that it may only imperfectly capture the underlying objective. See Goetz and Scott, 89 Yale L J at 1290-91 (cited in note 3). Compare Isaac Ehrlich and Richard A. Posner, An Economic Analysis of Legal Rulemaking, 3 J Legal Stud 257, 267-71 (1974) (explaining how precise rules generate costs of overinclusion and underinclusion).

${ }_{94}$ See Childres, $72 \mathrm{Nw} \mathrm{U} \mathrm{L} \mathrm{Rev} \mathrm{at} 837$ (cited in note 9).

${ }_{95}$ Among the many difficulties of using lost profits measures accurately is the tendency of courts to accept average cost data as the basis for estimating lost profits. See, for example, American Metal Climax, Inc. $v$ Essex International, Inc., 16 UCC Rep 101, 115 (S D NY 1974). Whenever the seller's marginal costs are increasing, average cost data is inaccurate. For a detailed discussion of this point, see Goetz and Scott, 31 Stan L Rev at 358-64 (cited in note 13). 


\section{B. Measuring Damages Under the Uniform Commercial Code}

While the UCC has abandoned the available market test of the common law, the drafters did retain a strong preference for market damages, a preference largely ignored in the recent debate over lost profits.

\section{Seller's damages under the Code.}

a) Seller's market damages. Assume a buyer repudiates a fixed-price contract to purchase goods and the seller sues for damages. How should the seller's damages be measured? The UCC's compensation principle requires that the seller receive damages sufficient to place it in as good a position as if the buyer had fully performed. ${ }^{98}$ However, as we have seen, the full performance compensation principle disguises a fundamental ambiguity: is the contractual expectancy to be determined ex ante, at the time of contract, or ex post, at the time for performance? The UCC does not resolve the ambiguity explicitly. Nevertheless, the recent enthusiasm of courts and commentators for lost profits overlooks the UCC's retention of the common law preference for market damages.

The UCC provides the seller two alternative methods for measuring losses by market damages. ${ }^{97}$ The seller can resell the goods under $\S 2-706$ and use the resale price to establish the price shift from the time of contract. ${ }^{98}$ Alternatively, the seller may proceed under $\S 2-708(1)$ and establish the price fluctuations by proof of the market price at the time and place of performance. ${ }^{9 \theta}$ What would induce the seller to choose one measure over another? By reselling under § 2-706, the seller can fix the price differential with certainty, thus avoiding the proof problems of establishing the relevant market price. The seller's "proof" under § 2-706 is the contract price and the resale price, minimizing litigation costs.

ө8 UCC § 1-106.

${ }^{97}$ The UCC recognizes that because damages may be difficult to prove, breach may impose losses that exceed compensatory damages. Thus, the UCC provides the aggrieved seller with flexibility in responding to the buyer's breach. The seller enjoys an advantage in selecting the remedy that will minimize breach costs. In turn, the injured party's obligation to mitigate damages helps ensure efficient salvage responses.

${ }^{88}$ Section 2-706 of the UCC provides that if the seller resells the goods in good faith and in a commercially reasonable manner, it is entitled to measure loss by the difference between the contract and resale prices.

${ }^{\text {89 }}$ UCC $\S 2-708(1)$. Theoretically this measure parallels $\S 2-706$ by identifying what a resale would have brought had the seller elected to resell in the market. 
But this advantage does carry other costs. To establish market damages by resale, the seller must comply with a number of specific conditions. ${ }^{100}$ It may well be that the uncompensated costs (lost business opportunities) imposed by compliance with a regulated resale are greater than any advantage in reducing anticipated litigation costs. Thus, the UCC offers the seller the alternative of reselling without supervision and instead relying on independent evidence of the market price to establish damages. ${ }^{101}$ This option permits a seller to return goods to inventory, rather than promptly reselling them, and to recover damages based on a hypothetical resale.

Several commentators have criticized the option under $\S 2$ 708(1) of establishing the market fluctuation by proving market price. Professor Childres advanced the argument, for example, that a seller should be compelled to resell under $\S 2-706 .{ }^{102} \mathrm{He}$ argued that resale is the only accurate measure of a given seller's market alternatives because the $\S 2-708(1)$ mechanism relies on a hypothetical market sale. But gains in accuracy are not socially desirable if purchased at the price of even greater uncompensated breach costs. Requiring resale in all cases invites strategic behavior by the breaching buyer, who is motivated to challenge the seller's compliance with the more complex statutory requirements of $\S 2-706$. Furthermore, the tradeoff between the more accurate but complex option of $\S 2-706$ and the clear but crude alternative of $\S 2-708(1)$ will vary in particular cases. The injured seller bears all the uncompensated costs, and has ample motivation to select whichever option minimizes its potential exposure. Thus, providing a choice to the party who suffers the consequences of any miscalculation reduces the costs of enforcing market damage rules.

Professors White and Summers are also troubled by the fact that the UCC may not preclude a seller from seeking recovery under $\S 2-708(1)$, even when the seller has resold the goods in a manner that suggests that recovery was available under the resale provisions of $\S 2-706 .{ }^{103}$ Assume that Buyer breaches a contract for

100 Section 2-706(2) permits the resale by either private or public auction. Both types of resale require reasonable notification to the buyer and must be "reasonably identified" as referring to the broken contract. The public sale imposes additional conditions.

101 Section 2-723(2) moderates the difficulty in establishing market price at the time and place of tender. Upon notice to the other party, the injured party may introduce evidence of the price prevailing within a reasonable time before or after the time of tender or at any other place which could serve as a reasonable substitute.

${ }_{102}$ Childres, $72 \mathrm{Nw} \mathrm{U} \mathrm{L} \mathrm{Rev} \mathrm{at} 837$ (cited in note 9).

${ }^{103}$ White and Summers, 1 Uniform Commercial Code $\S 7-7$ at 351-52 (cited in note 9). 
$\$ 10,000$. Resale occurs in Seller's local market without formal notification to Buyer and brings $\$ 8,000$. Assume also that Seller can establish that the market price at the time and place of tender (Seller's market) was $\$ 7,000$. Under these conditions, allowing Seller to recover $\$ 3,000$ market damages under $\S 2-708(1)$ appears to provide a windfall gain of $\$ 1,000$. In such a case, White and Summers argue, the full performance compensation principle (embodied in $\S 1-106$ ) demands that Seller be limited to its $\$ 2,000$ recovery under $\S 2-706 .{ }^{104}$

Visualizing these damage alternatives from the ex ante perspective demonstrates why Seller's recovery of $\$ 3,000$ market damages is not a windfall gain. A market contract does not purport to reflect ex post circumstances. Rather, it protects the parties' ex ante expectancy. At the time of breach, Seller cannot systematically predict which market alternative (if any) will yield the greater recovery. In theory, these are equivalent measures; over time, arbitrage will generate a uniform market price. Thus, the Seller's expected recovery in either case is exactly the same. Seller cannot outguess the market consistently, so it will select whichever option minimizes breach costs-which is exactly what the parties would bargain for. ${ }^{105}$ Even if Seller's actions result in an ex post windfall gain in a particular case, the gain should belong to the Seller because it also bears the risk of an unfavorable resale. If, for example, Seller was only able to resell for $\$ 6,000$, it would suffer $\$ 1,000$ in uncompensated costs. Because the specific conditions of $\S$ 2-706 would not be satisfied, § 2-708(1) would limit recovery to the $\$ 3,000$ shift in the market price.

An ex post perspective on market damages is not only misguided in theory, but contravenes the letter of the statute and the policy underlying the UCC's treatment of damages. The UCC emphasizes the primacy of market damages for market contracts and the correlative right to choose among alternative methods of measuring that loss. ${ }^{108}$ At least on an intuitive level, the drafters seemed to understand that an ex ante approach to damage meas-

104 Id at 352 .

108 This argument first appeared in Thomas H. Jackson, "Anticipatory Repudiation" and the Temporal Element of Contract Law: An Economic Inquiry into Contract Damages In Cases of Prospective Non-Performance, 31 Stan L Rev 69, 110, 115-16 (1978).

${ }^{108}$ Under UCC $\S 2-703$, the seller may either resell pursuant to $\S 2-706$ or prove market prices under $\S 2-708(1)$. Comment 1 to $\S 2-703$ emphasizes that "this Article rejects any doctrine of election of remedy as a fundamental policy and thus the remedies are essentially cumulative in nature and include all of the available remedies for breach." See also UCC $\S$ 2-706, Comment 2. 
urement furthers the contractual purposes of the parties. The choice between $\S 2-706$ and $\S 2-708(1)$ is an important part of efficacious enforcement against a breacher tempted to evade its contractual responsibility. In turn, assuring a seller that it will be able to enforce the contractual damage rule at reasonable cost protects the favorable market shift that was purchased with the fixed price contract.

b) Lost profits. When may the seller use the UCC's lost profits measure instead of the market damages alternatives? The common law focused on the absence of an available market. Where there was no available market for the goods, the common law (and the various sales acts) departed from the requirement that the seller replace the breached contract by reselling the contract goods. While the UCC no longer uses the available market formulation, it plainly directs the same result. Thus, the seller of special order goods (where presumably there is a thin resale market) can either complete performance and recover the full purchase price, ${ }^{107}$ or discontinue an incomplete performance and recover its estimated profits by establishing through direct proof the changes in revenues and costs caused by the breach. ${ }^{108}$ The UCC makes lost profits available whenever market damages are "inadequate to put the seller in as good a position as performance would have done. . . ."108 The seller clearly merits lost profits under this provision when, after breach, he chooses to cease production and salvage the components of specially manufactured goods. ${ }^{110}$ The con-

107 Under UCC § 2-709(1)(b) the seller can recover the purchase price of identified goods if it is "unable after reasonable effort to resell them at a reasonable price. . .." Courts have generally held that $\S 2-709(1)(b)$ applies when there is no ready or available market for the goods. See, for example, Cole $v$ Melvin, 441 F Supp 193, 205 n 7 (D SD 1977). Courts permit an action for the price in such cases because they doubt the fundamental assumption of market damages-that the seller can generally resell the goods more effciently because selling is his business. Moreover, not only resale costs result from a breach. The seller's risk of uncompensated breach costs is greater whenever the market is too thin to provide reliable evidence of comparable prices. See Alan Schwartz and Robert E. Scott, Sales Law and the Contracting Process 355-63 (Foundation, 2d ed 1990).

${ }^{108}$ UCC $\S 2-704(2)$ permits a seller exercising reasonable commercial judgment to terminate production and salvage its components. See Goetz and Scott, 31 Stan L Rev at 35861 (cited in note 13). See also cases cited in note 110.

109 UCC \& 2-708(2).

110 See, for example, Timber Access Industries Co. v U.S. Plywood-Champion Papers, Inc., 263 Or 509, 503 P2d 482, 489-91 (1972); Chicago Roller Skate Mfg. Co., Inc. v Sokol Mfg. Co., 185 Neb 515, 177 NW2d 25, 27 (1970); Autonumerics, Inc. v Bayer Industries, Inc., 144 Ariz 181, 696 P2d 1330, 1340 (App 1984). See also Neumiller Farms, Inc. $v$ Cornett, 368 S2d 272, 275 (Ala 1979) ("It is implicit within [§ 2-708], that, in order to employ the damage formula of subsection (1), there must not only exist a market for the con- 
troversial issue is whether the UCC expands access to lost profits. The UCC drafters failed to specify more precisely when the award of lost profits is appropriate, but both the Comments and legislative history reveal that their uncertainty stemmed from cases granting lost profit awards to volume sellers (generally retailers or jobbers) who thought market damages undercompensatory.

c) Solving the lost volume problem under the UCC. The lost volume problem clearly remains vexing. I have argued that the optimal damage rule would compensate the plaintiff seller for any market price shift as well as for the selling efforts "consumed" in the effort to secure the breached contract. ${ }^{111}$ Under the optimal default rule, therefore, damages would be less than the estimated profits per contract (the recovery presumptively available under $\S 2-708(2)$ ), but more than market damages plus post-breach incidental expenses (the recovery presumptively available under $\S \S 2$ 708(1) and 2-710). The challenge is to find a consistent interpretation of the various UCC provisions that better approximates the optimal default rule for lost volume cases.

Many courts and commentators would permit lost volume sellers to seek damages under $\S 2-708(2)$. This approach appears consistent with the statutory language and with the drafters' apparent belief that volume sales require careful attention to the position the seller would have achieved upon performance. But, as the discussion above has shown, a lost profits rule in lost volume claims invites excessively large awards. ${ }^{112}$ The award of lost profits is not a good proxy for the lost selling efforts. A significant portion of those "profits" covers sale completion costs and fixed overhead that the breaching buyer does not consume. ${ }^{113}$ Thus, recovery under $\S 2-708(2)$ of "the profit (including reasonable overhead) which the seller would have made from full performance" will always exact a cancellation penalty from the buyer in a sum greater than most parties would have stipulated had they bargained over

tracted goods, but also the aggrieved seller must have a legal obligation to enter that market to avoid the foreseeable adverse consequences of . . . breach. Unless there is a market ... . the subsection (1) measure of damages is functionally inadequate and the aggrieved seller may seek redress through . . . subsection (2).").

111 See text following note 91 .

112 Because performance, by definition, never occurs, what would have happened is always a matter of conjecture. Seller can never in fact show that the breach caused the "loss" of a sale. But the breach does cause Seller to suffer uncompensated selling costs.

113 In the fishing model, sellers intent on enlarging their market would not charge the fish that got away with the costs of cleaning the catch or with the amortized cost of the fishing boat. See text accompanying notes 84-85. 
the issue in advance. ${ }^{114}$ Moreover, $\S 2-708(2)$ specifies, in addition, that seller is entitled to "any incidental damages [under § 2-710]." Because the selling costs recovered under the guise of lost profits include post-breach and post-contract selling activities, this language specifically invites courts to grant sellers a double recovery for post-breach incidental costs.

Permitting recovery of lost profits for volume sellers under $\S$ 2-708(2) thus places on the retail buyer (often a consumer) the daunting burden of establishing the amount by which the estimated profits exceed the actual selling costs consumed in securing the breached contract. Viewed simply as a question of procedural efficiency, this outcome seems perverse. The plaintiff-seller enjoys the comparative advantage in assembling and presenting evidence of the selling costs attributable to the breach. A default rule that shifts the burden to the buyer both increases the costs and reduces the accuracy of legal enforcement. Indeed, it is likely that expected enforcement costs will exceed any anticipated returns from litigating the accuracy of an award under $\S 2-708(2)$. If so, the ultimate effect of using $\S 2-708(2)$ to compensate lost volume sellers will be to institutionalize a severe and socially wasteful cancellation policy. First, a lost profits rule gives most sellers more protection against cancellation than they could plausibly want. ${ }^{115}$ Second, the amount of the insurance coverage is based on factors (such as seller's costs) that buyers cannot determine except at great cost. The resulting uncertainty degrades product quality with no benefit accruing to either party. ${ }^{116}$

Consider the alternative rule: volume sellers receive market damages under $\S 2-706$ or $\S 2-708(1)$ together with incidental damages under $\S 2-710$. The recovery of any shift in the market price between contract and delivery is not problematic. The issue turns solely on the calculation of incidental damages. Recall that the volume seller's expectancy upon signing the contract is the opportu-

\footnotetext{
114 See text accompanying notes 88-92.
}

115 See text accompanying notes 86-91.

11 Two sources provide ad hoc evidence of the inefficiency of a lost profits rule for volume sellers. One source is the infrequency of litigation over lost profits awards. See Goetz and Scott, 31 Stan L Rev at 323, $351 \mathrm{n} 65$ (cited in note 13). The other is the prevalence of liberal policies among retailers on cancellations and returns. Retail volume sellers who do sue breaching buyers usually ask nothing more than market damages plus incidental expenses, despite the widely publicized recoveries in cases such as Neri. See cases cited in note 117. These sources suggest that most parties either opt out of the lost profits rule and stipulate a cancellation fee, often a nonrefundable deposit, or bargain after breach for some relaxation of the lost profits rule. The current preference for lost profits generates these socially wasteful bargaining costs. 
nity to complete the deal at the time of performance. Performance would have earned seller that opportunity; breach has foreclosed it. To satisfy the full performance compensation principle, seller must receive damages equal to the lost contractual opportunity. The value of the foregone opportunity, however, is not measured by the value of the contract per se, but by the pro rata selling costs consumed in dealing with the breaching buyer.

The statutory language of $\S 2-710$ seems broad enough to embrace post-contract as well as post-breach reliance costs. The costs consumed in securing the breached contract could be recoverable as "expenses . . . incurred . . . in connection with return or resale ... or otherwise resulting from the breach."117 Nevertheless, courts have generally awarded volume sellers only the post-breach expenses incurred in reselling the goods. ${ }^{118}$ This general rule should be qualified in several respects, however. First, volume sellers who choose to recover market damages rather than lost profits never request, much less prove, the selling costs attributable to the breached contract. ${ }^{119}$ Second, courts have explicitly limited the re-

117 UCC § $2-710$ (emphasis added).

118 See cases cited in note 120. See also Afram Export Corp. $v$ Metallurgiki Halyps, S.A., 772 F2d 1358, 1369 (7th Cir 1985) (seller not entitled to time value of the money tied up in the contract when a buyer breaches); Serna, Inc. $v$ Harmon, 742 F2d 186, 190 (5th Cir 1984) (incidental damages limited to damages occurring after the breach); Sprague $v$ Sumitomo Forestry Co., Ltd., 104 Wash 2d 751, 709 P2d 1200, 1206 (1985) (loss of logging time an inappropriate item of incidental damages since the loss did not arise within the scope of the breached contract); Malone v Carl Kisabeth Co., Inc., 726 SW2d 188 (Tex Civ App 1987) (incidental damages limited to those costs that result in direct expense for seller); Schiavi Mobile Homes, Inc. v Gironda, 463 A2d 722, 726-27 (Me 1983) (plaintiff can recover "floor plan interest" actually paid but not "wholly hypothetical charges" arising out of seller's use of his own funds to pay off a loan); Brownie's Army \& Navy Store, Inc. v E. J. Burke, Jr., Inc., 72 AD2d 171, 424 NYS2d 800, 804 (1980) (incidental damages under $\S 2$ 710 restricted to "commercially reasonable charges"; the words "or otherwise resulting from the breach" do not expand the section to include attorneys' fees); Smith $v$ Joseph, 31 UCC Rep 1560, 1565 (DC Super 1981) (volume seller limited to costs of placing a classified ad for the three weeks between breach and resale); Cohn v Fisher, 118 NJ Super 286, 287 A2d 222, 228 (1972) (retail seller awarded additional expenses including resale charges, storage charges, and notice charges occasioned by buyer's default on a contract for sale of a boat).

110 In approximately a dozen reported cases under the UCC, volume sellers have chosen to recover market damages plus incidental damages rather than lost profits. Nine of these resulted in awards of all the incidental costs plaintiffs requested. See Bulk Oil (U.S.A.), Inc. $v$ Sun Oil Trading Co., 697 F2d 481, 483-84 (2d Cir 1983) (post-breach interest payments allowed); Intermeat, Inc. $v$ American Poultry, Inc., 575 F2d 1017, 1024 (2d Cir 1978) (financing charges attributable to contract goods allowed); Atlas Concrete Pipe, Inc. $v$ Roger J. Au \& Son, Inc., 467 F Supp 830, 840-41 (E D Mich 1979) (plaintiff entitled to increased cost of capital because buyer failed to pay on open account); Cole v Melvin, 441 F Supp 193, 207 (D SD 1977) (recovery of cost incurred in care and feeding of cattle after breach); Lee Oldsmobile, Inc. $v$ Kaiden, 32 Md App 556, 363 A2d 270, 272, 276 (1976) (plaintiff recovered sales commissions, brokers' commissions, floor plan interest and transportation expenses); 
covery of incidental damages to post-breach expenses only for claims brought under $\S 2-708(2)$, which may reflect the intuition that the plaintiff is seeking a double recovery. ${ }^{120}$ In short, the barriers to using § 2-710 to compensate the losses of a volume seller may be much lower than is commonly assumed. If sellers must introduce those costs via $\S 2-710$, the procedural efficiency of the damage rule increases; sellers in general enjoy the comparative advantage in establishing uncompensated selling costs.

The preceding argument may prove too much, however. It is quite possible, especially in the case of the retail volume seller, that one cannot tease the ideal default rule out of the UCC's statutory language, especially with its judicial gloss. There are several reasons, however, to prefer the inadequacies of market damages to the excesses of lost profits. Certain default rules are set not because they represent the ultimate allocations preferred by most bargainers, but rather because they best induce one party to share important information with the other. ${ }^{121}$ Consider the familiar foreseeability limitation on consequential damages embodied in Hadley $v$ Baxendale. ${ }^{122}$ Limiting damages for the unforeseeable

Procter \& Gamble Distributing Co. v Lawrence American Field Warehousing Corp., 16 NY2d 344, 213 NE2d 873 (1965) (incidental recovery included extra transportation, legal expense and other "costs to which [seller] was subjected by buyer's default"); Peoria Harbor Marina v McGlasson, 105 Ill App 3d 723, 434 NE2d 786, 792 (1982) (recovery of interest accrued from the date of resale); Smith $v$ Joseph, 31 UCC Rep 1560, 1565 (DC Super 1981) (recovery of advertising costs); Cohn v Fisher, 118 NJ Super 286, 287 A2d 222 (1972) (plaintiff granted resale costs).

The remaining cases represent refusals to award attorney's fees or other speculative losses. See East Girard Savings Ass'n v Citizens National Bank and Trust Co. of Baytown, 593 F2d 598, 604 (5th Cir 1979) (no attorneys' fees); Ernst Steel Corp. v Horn Construction Division, Halliburton Co., 104 AD2d 55, 481 NYS2d 833, 836-40 (1984) (no recovery of implied interest or implied storage costs); Brownie's Army \& Navy Store, 424 NYS2d at 804 (same); Schiavi Mobile Homes, 463 A2d at 726-27 (no recovery for "wholly hypothetical" implicit interest claimed by seller who used his own funds to pay off a loan).

${ }^{120}$ See, for example, Neri, 285 NE2d at 315 (attorneys' fees not in the nature of the protective expenses contemplated); The Great Western Sugar Co. v Mrs. Alison's Cookie Co., 563 F Supp 430, 433-34 (E D Mo 1983) (recovery denied for attorneys fees and for direct costs bearing on the profits expected under the breached contracts, such as payment owed to beet growers as a percentage of average net return on sales); USX Corp. $v$ Union Pacific Resources Co., 753 SW2d 845, 856 (Tex Civ App 1988) (since seller was claiming as a lost volume seller, expense of acquiring supplies not recoverable as incidental damages); Industrial Circuits Co. $v$ Terminal Communications, Inc., 26 NC App 536, 216 SE2d 919, 922-24 (1975) (no damages allowed for "bill back" charges resulting from loss of volume discount).

${ }^{121}$ See Scott, 19 J Legal Stud at 609-11 (cited in note 65) (discussing default rules that force information in commercial contracts); Ian Ayres and Robert Gertner, Filling Gaps in Incomplete Contracts: An Economic Theory of Default Rules, 99 Yale L J 87 (1989) (formal analysis of "penalty" defaults).

1229 Ex 341, 156 Eng Rep 145 (1854). 
consequences of breach induces the promisee to disclose to the promisor private information concerning the consequences of breach, thus stimulating the transmission of mutually beneficial information between the bargainers. ${ }^{123}$

This information-forcing dimension may explain the commonlaw preference for market damages even in the context of volume sales. The market damages rule induces the seller to bargain for a more appropriate cancellation rule. By allocating the risk of cancellation to the party who possesses the key information concerning the costs of breach, the UCC would motivate specially designed provisions to cope with the lost volume problem. ${ }^{124}$

Even those parties who are not induced to opt out of the market damages rule would be better off than they would be under a lost profits regime. There are strong reasons to believe that most parties would assign the risk of a lax cancellation rule to the seller rather than place the equivalent risk of a harsh rule on the buyer. At least in the retail context, sellers are better able to spread the risk than customers. Moreover, the market damages rule, whatever its inadequacies, enjoys the great advantage of clarity. Both parties can better evaluate the expected deviation from the ideal than they could under the more complex and less certain lost profits rule.

d) Solving Nobs Chemical under the UCC. Solving the lost volume case through a sensitive interpretation of the market damage rules has an additional benefit. It permits courts to resurrect the common law "available market" test as the mechanism for

${ }^{123}$ Goetz and Scott, 89 Yale L J at 1299-1300 (cited in note 3); William Bishop, The Contract-Tort Boundary and the Economics of Insurance, $12 \mathrm{~J}$ Legal Stud 241 (1983); Ayres and Gertner, 99 Yale L J at 101-04 (cited in note 121).

124 Ayres and Gertner analyze the information-forcing properties of a market damages rule. 99 Yale L J at 104-05 (cited in note 121). See also Goldberg, $57 \mathrm{~S}$ Cal L Rev at 294-97 (cited in note 11). Goldberg concludes that market damages are the preferable default rule because they would motivate sellers to negotiate for fixed deposits. He argues that although lost profits accurately measure the expected costs of breach, most parties would still prefer a market damages default rule. He claims that sellers know more than buyers about the expected costs of cancellation, including the probability of breach. Thus, by manipulating the damage rule, the law can encourage sellers to disclose these facts. Two problems weaken this argument. First, buyers' uncertainty about the product's attributes should prompt sellers to reveal any special information about the probability and impact of breach. Second, by assuming that the seller knows the probability of breach better than the buyer, Goldberg confuses statistical probability with the probability of breach in a given case. To be sure, the seller knows better the likelihood that a buyer will breach on average. But the probability of breach for any particular buyer is not a function of statistical probability, but of the peculiar circumstances of that particular buyer. Thus, the buyer can anticipate and control its own behavior, and take cost-effective precautions that reduce the probability of breach. 
regulating the access to lost profits awards. In turn, courts would be less tempted to follow cases such as Nobs Chemical in using $\S 2-708(2)$ as a means of limiting the seller's market recovery.

At first glance, the plain language of the statute seems to control the choice between market damages and lost profits as a remedy limitation. Access to $\S 2-708(2)$ is only permissible when the recovery of market damages is "inadequate" to provide the seller its post-performance expectancy. By clear implication, the UCC does not sanction a lost profits measure on the grounds that market damages are "excessive." But the court in Nobs Chemical relied on the broad remedial statement in $\S 1-106$ to trump the more specific statutory language of $\S 2-708(2)$.

The Nobs Chemical court claims to identify a fundamental incompatibility between market damages under $\S 2-708(1)$ and the compensation principle of $\S 1-106$. In fact, this "incompatibility" arises from confusion between ex ante and ex post perspectives. The UCC scheme reflects an intuitive understanding that fixedprice market contracts allocate market risks. Thus conceived, market damages in cases such as Nobs Chemical do not overcompensate. Rather, they grant the seller the benefit of its bargain. A fixed-price market contract is the purchase of an option on the future goods at the contract price. The contractual expectancy is the right to have those goods at that price at the date of performance. Any limitation of damages based on subsequent events frustrates that expectancy. Indeed, only market damages will satisfy the injunction in § 1-106 to "put the aggrieved party in as good a position as if the contract had been fully performed." 125

125 At least one court has come close to recognizing that the full performance principle must not trump the overarching principle that the plaintiff receive the benefit of the bargain. In Trans World Metals, Inc. v Southwire Co., 769 F2d 902 (2d Cir 1985), the parties negotiated a contract for the delivery of twelve thousand tons of aluminum at a fixed price of 77 cents per pound. Between April 1981, when the contract was negotiated, and March 1982 , the price of aluminum fell dramatically. Buyer repudiated the contract in March 1982, after receiving and paying for the first of twelve monthly shipments. The court awarded the seller market damages of over $\$ 7,000,000$. The buyer argued that the seller should receive only lost profits based on the profit on the first shipment projected over the life of the contract.

The Second Circuit rejected the buyer's argument. First, the court held that nothing in the language or history of $\S 2-708(2)$ suggests that it should apply to cases in which market damages might overcompensate the seller. Second, the court did not think market damages would overcompensate the seller. Only the contract-market differential would award the seller the " 'benefit of its bargain'. . . . [I]t simply could not have escaped these parties that they were betting on which way aluminum prices would move." Id at 908 . Because the seller accepted the risk that prices would rise, it deserved to benefit from their fall. Distinguishing Nobs Chemical, the court noted that this seller had not laid off the contract risk with a 


\section{Buyer's damages under the UCC.}

The UCC's preference for market damages in the case of seller's breach is even more pronounced because here the UCC recognizes no lost profits option at all. ${ }^{126}$ The contract-market differential is the cornerstone of the buyer's damage alternatives. If there is an available market for the contract goods ${ }^{127}$ and the buyer never obtains or does not retain possession of the goods, ${ }^{128}$ the UCC directs the award of market damages. ${ }^{129}$ In such a case, the buyer's post-breach actions are normally not part of the bargainedfor exchange of risks. ${ }^{130}$

Thus, in the case of buyer's damages, the UCC adopts an ex ante perspective in allocating market risks. Not surprisingly, the drafters therefore sought to provide alternative methods of measuring the shift in market price in order to reduce the costs of enforcing the damage rule. Section 2-713 allows aggrieved buyers to recover the contract-market differential by establishing the market price prevailing at the time of the breach. ${ }^{131}$ In the alternative, § 2712 invites the buyer to establish the market shift by covering the contract with another seller. ${ }^{132}$ In theory, then, these are precisely equivalent methods of measuring the market price fluctuations. The choice between a hypothetical cover or an actual cover reduces

third party. Id.

${ }^{126}$ Plaintiff can recover lost profits in the proper case as additional consequential damages under UCC § 2-715(2).

${ }^{127}$ For goods specially manufactured or not generally available on the market, the buyer may pursue goods-oriented remedies such as specific performance under $\S 2-716$. See UCC § 2-716, Comment 3.

${ }^{128}$ If the buyer has accepted the goods, he may recover any loss in "value" should the goods not conform to contractual warranty. See UCC § 2-714(2).

129 Section 2-711 provides that where the seller breaches, the buyer may cover under $\S$ 2-712 and recover damages based on the contract-cover price differential, or recover damages under $\S 2-713$ based on the contract-market price differential. See also Peters, 73 Yale $\mathrm{L} J$ at $259-60$ (cited in note 9 ).

${ }_{130}$ The buyer can obtain consequential damages for any general requirements (such as the use of the goods at the date of delivery) and any particular requirements of which the seller had reason to know at the time of contract. See UCC $\S 2-715(2)(\mathrm{a})$.

${ }^{131}$ Section 2-713 measures the difference between the contract price and the market price at the time the buyer learned of the breach, together with incidental and consequential damages. See UCC $\S \S 2-711(b)$ and 2-713(1). Where proof of the current market price is difficult to establish, the buyer can, upon notice, show a comparable price at a comparable time and place. Under $\S 2-723(2)$ the court may consider such evidence if it serves as a reasonable substitute for the actual market, and if actual market data is not readily available.

132 Under $\S 2-712$, the buyer can recover the difference between the cost of cover and the contract price if the cover contract was made reasonably, in good faith, in substitution, and without unreasonable delay. 
the buyer's exposure to uncompensated breach costs. ${ }^{133}$ Choice permits the aggrieved buyer to select the option most likely to minimize breach costs in the particular case, with little or no risk that the buyer will manipulate the damage choices strategically. ${ }^{134}$

Commentators have strongly criticized the freedom granted the buyer under the UCC to select among these theoretically equivalent damage measures. Professor Childres has called for compulsory cover and the repeal of $\S 2-713 .{ }^{135}$ Professors White and Summers have argued that the drafters could only have meant $\S 2-713$ to be a statutory liquidated damages clause, a breach inhibitor which bears no close relation to the plaintiff's actual loss. ${ }^{136}$ White and Summers, for example, assume that ex ante market damages are always inconsistent with the principle of full performance compensation. Performance, they argue, would have given the buyer certain goods for consumption or resale. The consequence of performance would have been a specific economic gain or loss. The contract-market differential itself bears no necessary relation to the actual changes in the buyer's economic status caused by the

13s The aggrieved buyer faces the same problem as the aggrieved seller. Proof of market price is often a difficult burden and may depend upon evidence likely to be challenged by the seller. For evidence that sellers routinely contest estimates of market price, see ThreeSeventy Leasing Corp. v Ampex Corp., 528 F2d 993, 997-98 (5th Cir 1976); Maxwell v Norwood Marine, Inc., 58 Mass App 59, 19 UCC Rep 829, 831-32 (1976); Gulf Chem. \& Metallurgical Corp. v Sylvan Chem. Corp., 122 NJ Super 499, 300 A2d 878, 882-83 (1973). The buyer can reduce the costs of proof, and hence the risk of sellers evading their contractual responsibilities, by undertaking an actual cover under the specified conditions of the statute. A valid cover shifts to the seller the burden of proving the unreasonableness of the cover price. See $\S 2-712$, Comment 2 ("it is immaterial that hindsight may later prove that the method of cover used was not the cheapest or most effective").

Because the buyer must still show that the cover action was a reasonable substitute undertaken without unreasonable delay, the risk of seller's evasion shifts to strategic claims that the process, rather than the price, was inadequate.

${ }_{134}$ The UCC contemplates a free choice between the two alternatives. See UCC $\$ 2-712$, Comment 3 ("The buyer is always free to choose between cover and damages for non-delivery. ...").

Might the buyer behave opportunistically in seeking to exploit the breaching seller? There seems to be little opportunity for such exploitation. Assuming that the buyer cannot systematically outguess the market, the decision to purchase substitute goods outside the "protection" of § 2-712 should be at the buyer's own risk. Moreover, sellers may argue that a replacement contract made within the post-breach period was actually a cover. If the factfinder accepts this argument, the buyer could not use a higher estimate of the contractmarket differential. This result could stem either from a determination that the buyer had covered in fact ( $\$ 2-713$, Comment 5: market damages remedy of $\S 2-713$ "applies only when and to the extent that the buyer has not covered") or, more plausibly, from a determination that the evidence of cover price was conclusive as to the current market price under § 2-713.

${ }^{135}$ Childres, $72 \mathrm{Nw} \mathrm{U} \mathrm{L} \mathrm{Rev} \mathrm{at} 837$ (cited in note 9).

${ }^{138}$ White and Summers, 1 Uniform Commercial Code $\S 6-4$ at 294-95 (cited in note 9). 
breach. Thus, putting the buyer in the same position that performance would have cannot be the purpose of $\S 2-713 .{ }^{137}$

The argument that market damages violate the principle of full performance compensation has two distinct effects. First, it supports the claim that, notwithstanding the statutory language, actual cover under $\S 2-712$ should be the preferred or sole means of measuring market damages. ${ }^{138}$ As I have argued above, the principal consequence of so narrowing the injured parties' options is to increase the costs of enforcement by exposing the buyer to strategic manipulation by the breaching seller. ${ }^{138}$ Second, the argument lends credence to the claim that notwithstanding the statutory language, a buyer's damages should be limited to lost profits in appropriate cases. ${ }^{140}$

The recent case of Allied Canners \& Packers, Inc. $v$ Victor Packing $C_{0 .}{ }^{141}$ clearly illustrates the salience of the ex post perspective on damage measurement. Allied contracted with Victor to purchase 185,000 pounds of raisins at 30 cents per pound with a discount of 4 percent. Allied then contracted to resell the raisins to several Japanese firms at a fixed price that would have yielded $\mathrm{Al}$ lied a profit on delivery of $\$ 4,462$ if Victor had delivered raisins pursuant to the contract. Because of damage to the raisin crop, Victor breached. The market price of comparable raisins at the time of delivery was 87 cents per pound. Several of Allied's contracts with Japanese producers had a force majeure clause that likely would have excused Allied, but at least one purchaser insisted on performance. Allied subsequently sued Victor for $\$ 150,000$ in market damages under UCC $\S 2-713$. The California Court of Appeals denied the buyer's claim under $\S 2-713$ and instead limited the seller's liability to the "lost profits" of $\$ 4,462$.

The court concluded that market damages as measured by $\S 2$ 713 clashed fundamentally with the full performance compensation principle of $\S 1-106$. The court resolved the "conflict" by holding that the broader principle of full performance compensation trumps the narrower measure specified in $\S 2-713 .{ }^{142}$

The result in Allied Canners is unfortunate. As the discussion above has shown, the full performance compensation principle

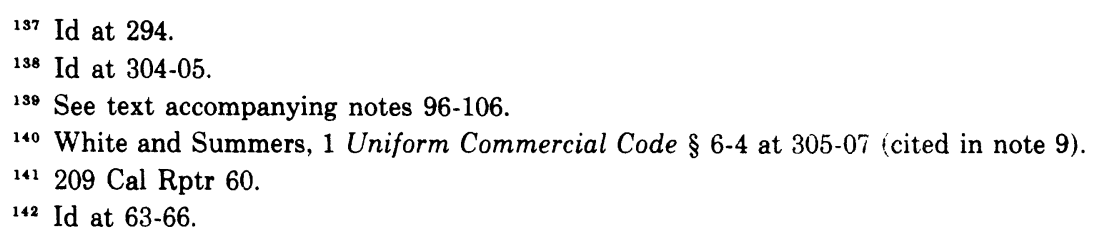


does not dictate the choice between the two alternative damage measures. Section 1-106 does no more than direct that the injured party receive the benefit of the contract. If the contract implies market damages as the default rule, then $\S 1-106$ is entirely consistent with a denial of the seller's lost profits defense. Indeed, only market damages will put such a buyer in as good a position as if the contractual opportunity had been realized.

One way to avoid the trap of measuring the contractual expectancy ex post is to focus on what the aggrieved party has purchased by the contract. The goods are purchased and sold at the time for performance. The function of the contract is to buy and sell an option on the future price of those goods. As with any option, the risk can be hedged by selling some (or all) of the option rights to a third party. Yet no one would seriously argue that when an option holder attempts to exercise its rights, the breacher can resist damages for non-performance by pointing to the post-contract actions of the option holder. The entitlement to market damages ensures that the injured party receives the benefit of its bargain.

\section{Conclusion: Toward a New Perspective on Damages for Breach of Market Contracts}

The strong inclination of courts to award lost profits damages is puzzling. In the case of remedy limitations, the courts show a remarkable willingness to award windfall gains to a deliberate breacher. In the lost volume cases, courts show an equally perplexing willingness to impose punitive damages on consumer buyers. What accounts for this persistent bias toward lost profits? One answer is the tendency of legal analysts to tell the story of contract breach ex post, and thus to define full performance compensation by reference to what has happened in a particular case. The discussion above has shown that one must measure full performance compensation at the time of contract, as though we did not know how the story would end.

The preoccupation with ex post compensation leads modern courts and commentators to assume that the parties to a market contract have bargained for completion of the contemplated exchange. Thus, for example, in the case of a jobber or a middleman who never acquires the contract goods, it is assumed that the seller is entitled to damages equal to the estimated profits from completed performance. From there it is a simple step to conclude that lost profits damages better measure the injured party's loss. Market damages do not necessarily match the estimated profits from completion. 
The error in the analysis is the assumption that the injured party's expectancy is his estimated profit. Market contracts involve different risks and different expectations. A fixed-price contract in a market context is an option on the future price or future supply. Compensatory damages should thus protect the value of the option, not of the completed performance. In the limited remedy case, the option is more valuable than the completed performance and a lost profits award undercompensates. On the other hand, in the lost volume case, the option is worth less than the completed performance, and lost profits damages are excessive.

This analysis follows from the fact that the legal remedy packaged with the contract is a part of the product sold. To the extent that the law starts the parties off with undesirable product features, such as a harsh cancellation policy that is not the optimal mix of legal rights and tangible product characteristics, a variety of unhappy circumstances can result. Volume sellers, for example, would prefer to exploit economies of scale over a wider range of customers by offering a more attractive option to cancel. By using a lost profits measure as the default rule, the law makes it more difficult for the parties to accomplish their contractual objectives.

These effects are similar to the consequences of using lost profits to limit market damages. Once one regards the legal remedies as part of the product, it is clear that the optimal product mix should not depend on conditions the buyer is unable to observe except at great cost. This, of course, is the point of the critical analysis of Nobs Chemical. The same is true of lost volume cases such as Neri. The threat of lost profits requires a buyer to undertake a complex inquiry into the seller's costs. In both instances, a market damages rule enables the buyer to determine the price of the product that he is purchasing at less cost. The seller, in turn, becomes able to offer products at different prices to different buyers. 